\title{
TALDICE-1 age scale of the Talos Dome deep ice core, East Antarctica
}

\author{
D. Buiron ${ }^{1}$, J. Chappellaz ${ }^{1}$, B. Stenni ${ }^{2}$, M. Frezzotti ${ }^{3}$, M. Baumgartner ${ }^{4}$, E. Capron ${ }^{5}$, A. Landais ${ }^{5}$, \\ B. Lemieux-Dudon ${ }^{6}$, V. Masson-Delmotte ${ }^{5}$, M. Montagnat ${ }^{1}$, F. Parrenin ${ }^{1}$, and A. Schilt ${ }^{7}$ \\ ${ }^{1}$ Laboratoire de Glaciologie et Géophysique de l'Environnement (UMR 5183, CNRS-Université Joseph Fourier - Grenoble), \\ , 38402 Saint Martin d'Hères cedex, France \\ ${ }^{2}$ Department of Geosciences, University of Trieste, 34127 Trieste, Italy \\ ${ }^{3}$ ENEA, CR Casaccia, 00123, Roma, Italy \\ ${ }^{4}$ Climate and Environmental Physics, Physics Institute, University of Bern, Sidlerstrasse 5, 3012 Bern, Switzerland \\ ${ }^{5}$ Laboratoire des Sciences du Climat et de l'Environnement (IPSL/CEA-CNRS-UVSQ UMR 1572), CEA Saclay, 91191 \\ Gif-sur-Yvette cedex, France \\ ${ }^{6}$ INRIA- Laboratoire Jean Kuntzmann B.P. 5338041 Grenoble cedex 9 France \\ ${ }^{7}$ Oeschger Centre for Climate Change Research, University of Bern, 3012 Bern, Switzerland
}

Received: 4 August 2010 - Published in Clim. Past Discuss.: 9 September 2010

Revised: 20 December 2010 - Accepted: 23 December 2010 - Published: 10 January 2011

\begin{abstract}
A new deep ice core drilling program, TALDICE, has been successfully handled by a European team at Talos Dome, in the Ross Sea sector of East Antarctica, down to $1620 \mathrm{~m}$ depth. Using stratigraphic markers and a new inverse method, we produce the first official chronology of the ice core, called TALDICE-1. We show that it notably improves an a priori chronology resulting from a one-dimensional ice flow model. It is in agreement with a posteriori controls of the resulting accumulation rate and thinning function along the core. An absolute uncertainty of only $300 \mathrm{yr}$ is obtained over the course of the last deglaciation. This uncertainty remains lower than 600 yr over Marine Isotope Stage 3, back to $50 \mathrm{kyr}$ BP. The phasing of the TALDICE ice core climate record with respect to the central East Antarctic plateau and Greenland records can thus be determined with a precision allowing for a discussion of the mechanisms at work at submillennial time scales.
\end{abstract}

\section{Introduction}

The sequence of the last deglaciation in Greenland is characterized by the succession of an abrupt warming (onset of Bølling, 14.6 kyr BP) followed by an abrupt cooling (onset of Younger Dryas, $12.9 \mathrm{kyr}$ BP) before a rapid return

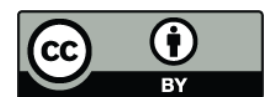

Correspondence to: J. Chappellaz (chappellaz@lgge.obs.ujf-grenoble.fr)
(11.6 kyr BP) to interglacial conditions (description structure from Johnsen et al., 1992; dates from Rasmussen et al., 2006). Such millennial scale climate variability is similar to that observed during the last glacial period, and has analogous climatic features in Antarctica. The Antarctic signal consists of a slow warming which precedes the abrupt transition in Greenland by about three thousand years. When Greenland temperature abruptly rises, a slow cooling starts in Antarctica (Blunier et al., 1997). Previous investigations of central East Antarctic ice cores have revealed the same consistent North-South timing and phasing for the sequence of the last deglaciation (Blunier et al., 1998; EPICA Community Members, 2006).

However studies of coastal ice cores in Antarctica have revealed a different pattern in two cases. The Taylor Dome site, situated near the Ross Sea, reveals a more Greenlandic-like evolution during the deglaciation (Steig et al., 1998). The first deglacial warming recorded in the Law Dome ice core situated in the Indian Ocean sector ends before the abrupt warming of the Bølling/Allerød (BA) in Greenland (Morgan et al., 2002). Questions however remain on the origin of such features that could notably be induced by dating errors. Currently there are few other ice cores from Antarctic coastal or near-coastal sites which cover the last $25 \mathrm{kyr}$ (for example Siple Dome (Brook et al., 2005), Byrd (Sowers and Bender, 1995; Blunier et al., 1998) and EPICA Dronning Maud Land (EDML) (EPICA Community Members, 2006) ice cores). The ice layers spanning the last deglaciation can be located close to bedrock where accurate dating is

Published by Copernicus Publications on behalf of the European Geosciences Union. 
challenging. Moreover coastal cores often undergo high variability of snow accumulation due to wind scouring, which can also affect the dating quality. For example the Siple Dome ice core situated west of the Ross Sea has recorded a nearly negligible snow deposition rate around $15 \mathrm{kyr} \mathrm{BP}$, leading to hiatus in the isotopic signal (Brook et al., 2005).

In order to document the regional variability of Antarctic climate, and its time relationship with climatic changes in other regions of the Earth (such as Greenland and the North Atlantic), a new deep ice core $(1620 \mathrm{~m})$ has been recovered at $5 \mathrm{~km}$ from the summit of Talos Dome $\left(159^{\circ} 11^{\prime} \mathrm{E}\right.$, $72^{\circ} 49^{\prime} \mathrm{S}, 2315 \mathrm{~m}$ a.s.l.) on the eastern edge of the East Antarctic plateau during the field seasons 2004-2008. The international TALDICE (TALos Dome Ice CorE) project (http://www.taldice.org) conducted by a consortium of five European nations led by Italy, is a contribution to the international project IPICS (International Partnerships in Ice Core Sciences; http://www.pages-igbp.org/ipics/index.html) of the International Polar Year 2007/2009. Talos Dome is an ice dome, roughly equally distant $(\sim 300 \mathrm{~km})$ to the Southern Indian Ocean and the Ross Sea. Its near-coastal location leads to a current accumulation rate of $8.5 \mathrm{~cm}$ ice equivalent per year (cm ie/yr) (Frezzotti et al., 2007; Stenni et al., 2002) i.e. about three to four times higher than on the East Antarctic plateau. It provides decadal time resolution during the last deglaciation period.

In addition to its focus on the last deglaciation (Stenni et al., 2011), the TALDICE project also intends to investigate the millennial-scale variability of the last glacial period, down to at least $50 \mathrm{kyr} \mathrm{BP}$, and to compare its shape and phasing with respect to other East Antarctic ice core records. Studying the sequence of climatic events between different areas relies on the quality of the ice core chronologies. The main techniques currently available for constructing ice core age scales can be grouped into four categories: (1) layercounting, a technique which requires annual layer resolution in snow deposition and in trace element measurements (not applicable in most Antarctic sites because the accumulation rates are not sufficient); (2) tuning of ice records to insolation changes (applicable for long ( $>100 \mathrm{kyr}$ ) records and resulting in large dating uncertainties - several kyr); (3) matching age markers to other well-dated time series; (4) glaciological models simulating the thinning and flow of snow/ice layers through the ice sheet.

Absolute ages are needed to analyse the links between climate and orbital forcing (e.g. Kawamura et al., 2007), and to depict the sequences of events recorded in different archives. Air trapped within polar ice contains global atmospheric tracers such as $\mathrm{CH}_{4}$ and $\delta^{18} \mathrm{O}_{\mathrm{atm}}$ that display temporal variability between different drilling sites (Landais et al., 2003). It is thus possible to build a relative dating of different polar ice cores that can provide insights into the timing of climatic events between Greenland and Antarctica and between different sites in Antarctica. A firn core was dated at Talos Dome by using seasonal variations in non-sea-salt sulphate concentrations coupled with the recognition of atomic bomb marker level (1965-1966) and sulphate spikes due to the most important volcanic events in the last 800 years (Stenni et al., 2002). Due to the difficulty of identifying seasonal signals and absence of absolute volcanic chronology before $1000 \mathrm{AD}$, it is impossible to build an absolute layer-counting age scale for ages older than the last millennium. As a consequence, we chose to build a relative glaciological age scale for Talos Dome. It is based on the absolute GICC05 age scale from Greenland down to $50 \mathrm{kyr}$ (Svensson et al., 2008) and on the EDC3 age scale from Antarctica for older ages (Parrenin et al., 2007a), using both records' synchronizations and glaciological modelling.

A new dating method based on inverse techniques has been recently developed (Lemieux-Dudon et al., 2009). It first requires background scenarios for the accumulation rate, the thinning function and the Close-Off-Depth in Ice Equivalent (CODIE) and the difference of depth for a given age between the trapped gas and the ice matrix ( $\Delta$ depth). The scenarios are provided by simulations (ice flow and snow densification modeling). It is then complemented with chronological data provided by age markers (data enabling the association of time with a specific depth). The efficiency of this method has already been illustrated by improving the consistency between EPICA/Dome C (EDC), EPICA Dronning Maud Land (EDML), and NorthGRIP age scales (Lemieux-Dudon et al., 2010) over the last $50 \mathrm{kyr}$.

There are three main potential added values from the inverse modeling method: (1) it can provide parallel and consistent dating of several cores, (2) both gas and ice tie points can be used, (3) most importantly it produces a consistent set of $\Delta$ age, accumulation rate and thinning function.

We aim here at applying this inverse method to obtain the TALDICE-1 age scale, thus taking benefit mostly from the third added value mentioned above. We provide the background scenario by conducting simulations with a 1-D ice flow model (Parrenin et al., 2004), coupled with a densification model (Arnaud et al., 2000). We define age markers through the use of $\mathrm{CH}_{4}$ and water isotopic profiles in the TALDICE and other ice cores. In order to match our new age scale to the absolute GICC05 age scale from Greenland (Svensson et al., 2008), most tie points are chosen through the synchronization of the TALDICE and Greenland methane records.

In this paper we first present the tie points (Sect. 2.4) and describe the background scenario (Sect. 3) and the use of the inverse method (Sect. 4). Results and uncertainties are then discussed, including a posteriori controls of the resulting TALDICE-1 age scale and of the glaciological entities reconstructed by the model. 


\section{Data and methods}

The quality of the chronology strongly depends on the number, distribution and quality of tie points along the record. The central tool used here to define tie points relies on synchronizing the TALDICE and other ice core $\mathrm{CH}_{4}$ profiles.

$\mathrm{CH}_{4}$ measurements have already been used many times for relative dating of ice cores (Blunier and Brook, 2001; Blunier et al., 1998, 2007; Chappellaz et al., 1997). During abrupt glacial events, $\mathrm{CH}_{4}$ shows large and abrupt changes with time, usually associated with Greenland temperature changes (Huber et al., 2006). Its atmospheric lifetime of about $10 \mathrm{yr}$ (Denman et al., 2007) is larger than the interhemispheric mixing time $(\sim 1 \mathrm{yr})$, thus making its mixing ratio changes of global significance. Similar $\mathrm{CH}_{4}$ records should thus be obtained in any ice core from either hemisphere. The limits of the $\mathrm{CH}_{4}$ tie points are (1) the existence of an interpolar gradient, not always well known, which introduces error in tie point definition when $\mathrm{CH}_{4}$ changes abruptly (Dällenbach et al., 2000); (2) the smoothing of atmospheric composition changes which can differ from one ice core to another due to different gas trapping conditions (Spahni et al., 2003); this may also bias the age at mid-slope of $\mathrm{CH}_{4}$ changes (Köhler, 2010); (3) the presence of time intervals where $\mathrm{CH}_{4}$ does not vary significantly, such as Marine Isotopic Stage 2 (MIS 2) (Blunier et al., 2007). Still, $\mathrm{CH}_{4}$ is particularly useful to date new Antarctic ice cores by matching them with the Greenlandic cores, as the reference $\mathrm{CH}_{4}$ signal is well-known back to $\sim 110 \mathrm{kyr}$ BP (Brook et al., 1996), and as the Greenland ice cores can be absolutely dated by annual layer counting (Andersen et al., 2006; Rasmussen et al., 2006; Svensson et al., 2008; Vinther et al., 2006).

Below $1428 \mathrm{~m}$ of depth in the TALDICE core, corresponding to a gas age of $\approx 141 \mathrm{kyr} \mathrm{BP}$, the resolution of our $\mathrm{CH}_{4}$ measurements is not sufficient for synchronization purposes. We thus extend the chronology by matching the TALDICE $\delta^{18} \mathrm{O}$ water isotopic profile with the EDC one on the EDC3 age scale (Parrenin et al., 2007a), making the assumption that the main features of climatic variations occurred in phase at both sites. This part of the chronology could be refined at a later date when more comprehensive gas measurements are available.

Finally a posteriori control of the $\mathrm{CH}_{4}$ tie points have been provided by measurements of the isotopic composition of molecular oxygen contained in the air enclosed in the ice $\left(\delta^{18} \mathrm{O}_{\mathrm{atm}}\right)$.

\subsection{Methane measurements}

$\mathrm{CH}_{4}$ has been measured both at Grenoble (LGGE) and Bern laboratories, using two different methods. First, both LGGE and Bern used the same method as for previous ice cores. It consists of a wet extraction method combined with gas chromatographic analyses (Chappellaz et al., 1997; Spahni et al., 2005). The obtained LGGE values are increased by
$6 \mathrm{ppbv}$ in order to be in good agreement with Bern values (Spahni et al., 2005).

798 samples have been measured between 73 and $1620 \mathrm{~m}$ of depth, with a mean $1 \sigma$ error of $10 \mathrm{ppbv}$. The mean depth resolution is $2 \mathrm{~m}$, and varies from $0.5 \mathrm{~m}$ during sharp transitions to $12 \mathrm{~m}$ in the worst case. Second, part of the record (between 667 and $817 \mathrm{~m}$ and between $1132 \mathrm{~m}$ and $1487 \mathrm{~m}$ of depth) has been measured using a new on-line technique where the gas eluted from a continuous-flow analysis (CFA) system is separated from water with a membrane and then transferred to a gas chromatograph, thus providing $\sim 20 \mathrm{~cm}$ depth resolution, but with a lower precision of the measurements ( $1 \sigma$ of 15 to 20 ppbv; Schüpbach et al., 2009).

\subsection{Water isotopic measurements}

Measurements of the oxygen isotope composition $\left(\delta^{18} \mathrm{O}\right)$ of water in the TALDICE samples were conducted on discrete samples averaging over a length of $1 \mathrm{~m}$. The $\delta^{18} \mathrm{O}$ measurements were carried out in France (Laboratoire des Sciences du Climat et l'Environnement) and in Italy (University of Trieste and Parma) using the well-known $\mathrm{CO}_{2}$ water equilibration technique (Epstein et al., 1953). Intercomparisons of reference waters among the involved laboratories were conducted over the analysis period and the same water standard was used in all laboratories. The precision of $\delta^{18} \mathrm{O}$ measurements is $\pm 0.05 \%$. The $\delta^{18} \mathrm{O}$ data provided here are the results of at least duplicate measurements of each sample, over a total of 1620 samples.

\subsection{Molecular oxygen isotopic measurements $\left(\delta^{18} \mathrm{O}_{\mathrm{atm}}\right)$}

We measured the $\delta^{18} \mathrm{O}_{\mathrm{atm}}$ on 145 TALDICE samples between 583 and $1402 \mathrm{~m}$, using the analytical technique described in (Landais et al., 2003). The mean $1 \sigma$ precision is $0.025 \%$.

\subsection{Synchronization and age marker assignments}

Down to $1191 \mathrm{~m}$ of depth $(\approx 50 \mathrm{kyr} \mathrm{BP})$ we matched the $\mathrm{CH}_{4}$ profile of TALDICE with the Greenland Composite methane curve published by (Blunier et al., 2007) which is based on the absolute layer-counted GICC05 age scale. The GICC05 age scale is considered as the current reference for ice core absolute dating down to about $50 \mathrm{kyr}$ BP (Svensson et al., 2008). It suggests that the TALDICE chronology should show a good coherency with absolute ages during this period.

Before $50 \mathrm{kyr} \mathrm{BP}$, the most accurate and detailed $\mathrm{CH}_{4}$ profile available is that of the EDC ice core (Loulergue et al., 2008). We thus extended the $\mathrm{CH}_{4}$ synchronization between TALDICE and EDC profiles on the EDC3 age scale between 50 and $141 \mathrm{kyr}$ BP (back to the onset of the penultimate deglaciation), corresponding to the depth range 1228$1428 \mathrm{~m}$ in the TALDICE ice core. The shift of the TALDICE matching between the Greenland and $\mathrm{EDC} \mathrm{CH}_{4}$ records 


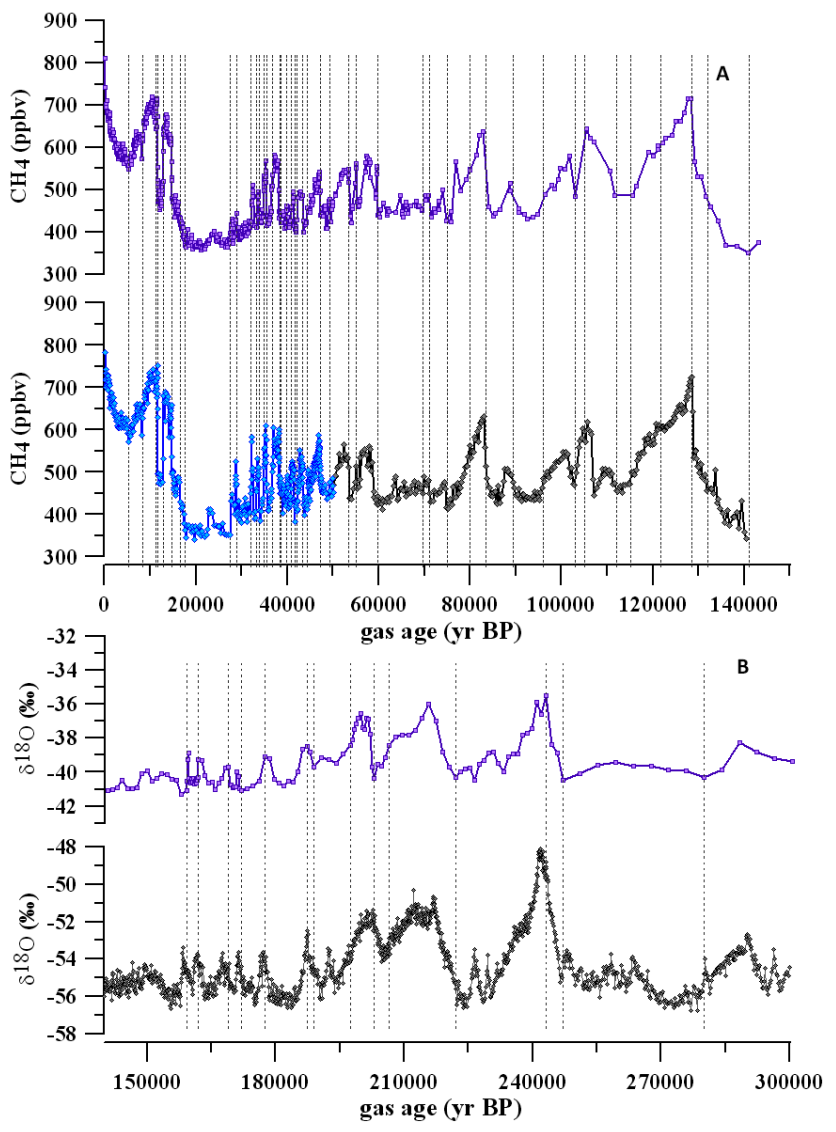

Fig. 1. (A): Synchronization of the TALDICE $\mathrm{CH}_{4}$ record (purple curve) with the Greenland $\mathrm{CH}_{4}$ composite on GICC05 age scale (Blunier et al., 2007) (blue curve) back to $53 \mathrm{kyr} \mathrm{BP}$, and with the $\mathrm{EDC} \mathrm{CH}_{4}$ record (grey curve) on EDC3 age scale (Loulergue et al., 2008) for ages older than $53 \mathrm{kyr}$ BP. (B): Synchronization between TALDICE (Stenni et al., 2011) (purple curve) and EDC (grey curve) ice cores on the EDC3 age scale (EPICA Community Members, 2004) using $\delta^{18} \mathrm{O}$ of ice. For both graphs, dashed lines indicate the location of each tie point.

takes place at $53.5 \mathrm{kyr}$ BP (tie point corresponding to the Dansgaard/Oeschger \#14 warming). A similar method has already been applied at EDML (EPICA Community Members, 2006) by synchronizing EDML and Greenland Composite methane profiles in order to investigate the GreenlandAntarctic timing of events down to $55 \mathrm{kyr}$ BP.

$\mathrm{CH}_{4}$ synchronization is performed by visual wigglematching, the tie points being chosen at mid-slope or maximum or minimum of $\mathrm{CH}_{4}$ changes depending on the signal shape. For the synchronization exercise between TALDICE and EDC ice cores we consider that each tie point between TALDICE and EDC should bear the same $\mathrm{CH}_{4}$ mixing ratio (no influence of the interpolar gradient). Köhler (2011) suggests that the $\mathrm{CH}_{4}$ age at mid-slope is shifted toward older ages by $58 \%$ of the width of age distribution of the trapped gases. Applied to EDML and NorthGRIP, this criterion leads to an additional synchronization error of less than $100 \mathrm{yr}$
Table 1. Tie points defined by $\mathrm{CH}_{4}$ record synchronization between TALDICE and Greenland ice cores on GICC05 age scale.

\begin{tabular}{|c|c|c|c|c|}
\hline $\begin{array}{l}\text { Greenland } \\
\text { reference } \\
\text { ice core }\end{array}$ & $\begin{array}{r}\text { NorthGRIP } \\
\text { depth }(\mathrm{m})\end{array}$ & $\begin{array}{r}\text { TALDICE } \\
\text { depth (m) }\end{array}$ & $\begin{array}{l}\text { Gas age } \\
(\mathrm{yr} \text { BP) }\end{array}$ & $\begin{array}{r}\text { Uncertainty } \\
(\mathrm{yr})\end{array}$ \\
\hline GRIP & 846.6 & 420 & 5200 & 200 \\
\hline GRIP & 1219.2 & 553 & 8250 & 150 \\
\hline GRIP & 1470.3 & 684 & 11300 & 200 \\
\hline GRIP & 1489.9 & 695 & 11650 & 100 \\
\hline GRIP & 1525.2 & 738 & 12850 & 100 \\
\hline GRIP & 1604.2 & 784 & 14680 & 100 \\
\hline GRIP & 1647.6 & 820 & 16550 & 500 \\
\hline GRIP & 1672.8 & 844 & 17650 & 300 \\
\hline GRIP & 1861.3 & 935 & 27550 & 300 \\
\hline GRIP & 1891.5 & 953 & 28900 & 200 \\
\hline GRIP & 1941.0 & 985 & 32100 & 200 \\
\hline GRIP & 1962.6 & 994 & 33250 & 200 \\
\hline GRIP & 1976.4 & 1006 & 33850 & 200 \\
\hline GRIP & 1991.8 & 1015 & 34800 & 200 \\
\hline GRIP & 2008.6 & 1025 & 35450 & 200 \\
\hline GRIP & 2029.0 & 1040 & 36700 & 200 \\
\hline NGRIP & 2072.2 & 1062 & 38350 & 200 \\
\hline GRIP & 2076.7 & 1070 & 38650 & 200 \\
\hline NGRIP & 2093.2 & 1082 & 39800 & 200 \\
\hline NGRIP & 2110.5 & 1095 & 40850 & 200 \\
\hline NGRIP & 2126.1 & 1099 & 41600 & 200 \\
\hline NGRIP & 2132.5 & 1111 & 42100 & 200 \\
\hline NGRIP & 2155.5 & 1123 & 43300 & 200 \\
\hline NGRIP & 2169.8 & 1135 & 44400 & 200 \\
\hline GISP & 2224.0 & 1170 & 47200 & 200 \\
\hline GRIP & 2252.4 & 1191 & 49270 & 400 \\
\hline
\end{tabular}

(Köhler, 2011). TALDICE having a larger accumulation rate than EDML, and thus a smaller width of age distribution, an even smaller synchronization error (about $80 \mathrm{yr}$ ) is expected. We do not include it in the following analysis. With this method, 44 age markers have been defined for the gas phase of the TALDICE core (Fig. 1 and Table 1 and 2).

We also define 14 tie points between TALDICE and EDC $\delta^{18} \mathrm{O}$ records, at mid-slope or maximum of the sharpest climatic transitions between 1443 and $1556 \mathrm{~m}$ in TALDICE, covering the period between 159.2 and $280 \mathrm{kyr}$ BP on the EDC3 time scale (Table 3). This approach assumes synchronous climate changes in Eastern Antarctica on multimillennial time scales, as suggested by the coherency observed between various ice core records (Watanabe et al., 2003). This assumption is also corroborated by the comparison of TALDICE and EDC in the younger part of cores (Stenni et al., 2011). Current $\mathrm{CH}_{4}$ data resolution in the corresponding TALDICE depth range becomes too low to provide good markers with respect to the $\mathrm{EDC} \mathrm{CH}_{4}$ profile. Contrary to the first $44 \mathrm{CH}_{4}$ tie points, the additional 14 defined by the $\delta^{18} \mathrm{O}$ records are located in the ice phase.

The uncertainty on the absolute age of each tie point would be obtained by adding the uncertainty of the visual matching 
Table 2. Tie points defined by $\mathrm{CH}_{4}$ record synchronization between TALDICE and EDC ice cores on the EDC3 age scale.

\begin{tabular}{rrrr}
\hline EDC depth (m) & $\begin{array}{r}\text { TALDICE } \\
\text { depth }(\mathrm{m})\end{array}$ & $\begin{array}{r}\text { Gas age } \\
(\mathrm{yr} \mathrm{BP})\end{array}$ & $\begin{array}{r}\text { Uncertainty } \\
(\mathrm{yr})\end{array}$ \\
\hline 924.9 & 1228 & 53500 & 200 \\
944.5 & 1239 & 55150 & 200 \\
998 & 1264 & 59800 & 1000 \\
1089.1 & 1302 & 69600 & 400 \\
1106.6 & 1308 & 71200 & 1000 \\
1145.3 & 1316 & 75000 & 1000 \\
1197.8 & 1326 & 80000 & 800 \\
1239.0 & 1333 & 83400 & 800 \\
1302.7 & 1345 & 89500 & 500 \\
1369.3 & 1356 & 96000 & 500 \\
1439.6 & 1370 & 103000 & 800 \\
1457.2 & 1373 & 105000 & 1500 \\
1515.4 & 1380 & 112000 & 1000 \\
1544.8 & 1385 & 115200 & 1500 \\
1622.0 & 1394 & 121700 & 2000 \\
1717.3 & 1410 & 128500 & 1000 \\
1763.6 & 1420 & 132000 & 2000 \\
1817.4 & 1428 & 141000 & 2000 \\
\hline
\end{tabular}

between $\mathrm{CH}_{4}$ or $\delta^{18} \mathrm{O}$ records (Tables 1, 2 and 3; manual shift of $\mathrm{x}$-axis of one record until match is lost), and the inherent uncertainty of the GICC05 and EDC3 age scales at the corresponding ages. Here we build TALDICE-1 on a relative scale with respect to GICC05 and EDC3. Therefore the inherent uncertainties of both time scales are irrelevant. The error induced by the interhemispheric $\mathrm{CH}_{4}$ gradient leads to synchronization errors reaching up to $50 \mathrm{yr}$ (Dällenbach et al., 2000). The visual matching uncertainty amounts to less than $50 \mathrm{yr}$ during the sharp transitions corresponding to the BA and Younger Dryas (YD) events, taking also into account the analytical uncertainty. On the other hand, the uncertainty amounts to several millennia for the oldest TALDICE ice, the largest portion of it being related with the poor resolution of the available $\delta^{18} \mathrm{O}$ profile. Future $\delta^{18} \mathrm{O}$ measurements at 5$\mathrm{cm}$ depth resolution will help us to improve this part of the TALDICE time scale.

In total, 58 age markers are now available to constrain the dating scenarios provided by glaciological models, the highest concentration of tie points being during the deglaciation (11 to $18 \mathrm{kyr}$ BP) and during MIS3 (29 to $55 \mathrm{kyr} \mathrm{BP}$ ) periods.

\section{A priori scenario}

The inverse method (Lemieux-Dudon et al., 2010) used to build the TALDICE-1 age scale requires prior guess for the accumulation rate (expressed in ice equivalent), the thinning function, and the CODIE. The latter is critical as the synchronization of $\mathrm{CH}_{4}$ records leads to age constraints on the gas
Table 3. Tie points defined by water isotopic record synchronization between TALDICE and EDC ice cores based on the EDC3 age scale.

\begin{tabular}{rrrr}
\hline $\begin{array}{r}\text { EDC depth } \\
(\mathrm{m})\end{array}$ & $\begin{array}{r}\text { TALDICE } \\
\text { depth }(\mathrm{m})\end{array}$ & $\begin{array}{r}\text { Associated age } \\
(\mathrm{yr} \mathrm{BP})\end{array}$ & $\begin{array}{r}\text { Uncertainty } \\
(\mathrm{yr})\end{array}$ \\
\hline 1888.7 & 1443 & 159200 & 2000 \\
1903.1 & 1462 & 162000 & 2000 \\
1938.0 & 1471 & 169000 & 2000 \\
1953.0 & 1480 & 172000 & 2000 \\
1979.0 & 1484 & 177500 & 2000 \\
2022.2 & 1493 & 187300 & 2000 \\
2031.2 & 1495 & 189000 & 2000 \\
2072.0 & 1500 & 197500 & 2000 \\
2105.5 & 1512 & 203000 & 3000 \\
2123.8 & 1516 & 206500 & 3000 \\
2197.1 & 1526 & 222000 & 3000 \\
2299.8 & 1545 & 243200 & 4000 \\
2318.1 & 1548 & 247000 & 4000 \\
2410.4 & 1558 & 290000 & 5000 \\
\hline
\end{tabular}

chronology. In order to translate the $\mathrm{CH}_{4}$ time markers into chronological constraints on the ice chronology, we need to estimate past TALDICE close-off depths (COD) where discrete air bubbles are formed, and thus the age difference between the trapped gases and the surrounding ice $(\Delta$ age $)$. At first order, both parameters depend on the accumulation rate and on surface temperature, determining for any given site at which depth pores become enclosed at the bottom of the firn.

\subsection{Prior guess: 1-D ice flow model and snow densification model}

In order to calculate a first a priori scenario for the three entities, we use the 1-D ice flow model developed by (Parrenin et al., 2007b) which combines ice flow modeling with a firn densification model (Arnaud et al., 2000). It calculates the age of the ice at a given depth with the following equation:

$\operatorname{age}(z)=\int_{0}^{z} \frac{1}{T(z) a(z)} d z$

where $z$ is depth (m), $T$ is the thinning ratio and $a$ is the initial annual layer thickness (i.e. accumulation rate in ice equivalent), deduced from the isotopic composition of the ice. The required density profile has been measured in the field at Talos Dome.

The ice flow model is then coupled with a firn densification model (Arnaud et al., 2000) which uses the ice age scenario combined with past accumulation rate and temperature scenario deduced from the water isotopic data. The densification model provides past CODIE and $\Delta$ age scenarios, enabling to calculate a chronology associated with the gas phase of the ice core. 
Table 4. Input parameters used in the 1-D ice flow model (Parrenin et al., 2007b).

\begin{tabular}{llll}
\hline Parameter & Meaning & Value & References and comments \\
\hline$\beta$ & $\begin{array}{l}\text { Glacial-interglacial amplitude } \\
\text { of accumulation rate changes }\end{array}$ & 0.0165 & Tuned for best fit of age markers \\
\hline$\alpha$ & $\begin{array}{l}\text { spatial slope of the present- } \\
\text { day isotopic thermometer }\end{array}$ & $5.04 \%{ }^{\circ} \mathrm{C}$ & $\begin{array}{l}\text { Frezzotti et al. (2004); } \\
\text { Magand et al. (2004) }\end{array}$ \\
\hline $\mathrm{A}_{0}$ & $\begin{array}{l}\text { Present-day } \\
\text { accumulation rate }\end{array}$ & $8 \mathrm{~cm} \mathrm{ie} / \mathrm{yr}$ & $\begin{array}{l}\text { Tuned for best fit of age markers; } \\
10 \% \text { lower than Stenni et al. (2002) }\end{array}$ \\
\hline $\mathrm{T}_{0}$ & $\begin{array}{l}\text { Present-day } \\
\text { surface temperature }\end{array}$ & $-41^{\circ} \mathrm{C}$ & Frezzotti et al. (2004) \\
\hline $\mathrm{p}$ & $\begin{array}{l}\text { parameter controlling the (non)-linearity } \\
\text { of the vertical velocity profile of ice }\end{array}$ & 3 & Parrenin et al. (2007b) \\
\hline$\Delta \mathrm{H}$ & Past elevation changes & Table 5 & See Sect. 3.2 \\
\hline
\end{tabular}

Past accumulation rates and temperature changes are usually deduced from the deuterium content of the ice $(\delta \mathrm{D})$. Since the full TALDICE $\delta \mathrm{D}$ record is not available yet, the $\delta^{18} \mathrm{O}$ data have been multiplied by 8 (Merlivat, 1978) to build a synthetic $\delta \mathrm{D}$ record. This approximation is based on the assumption that the second order parameter deuterium excess $\left(d=\delta \mathrm{D}-8 \delta^{18} \mathrm{O}\right)$ is negligible, but we must keep in mind that studies (e.g., Vimeux et al., 1999) have shown variations of more than $10 \%$ of $d$ in Antarctica during the last deglaciation period. We finally used the following equations:

$T=T^{0}+\alpha \Delta \delta D_{\mathrm{corr}}$

and

$A=A^{0} \exp \left(\beta \Delta \delta D_{\mathrm{smo}}\right)$

where $T^{0}$ and $A^{0}$ are the present-day surface temperature $\left({ }^{\circ} \mathrm{C}\right)$ and accumulation rate $(\mathrm{cm}$ ie/yr) at the drilling site. $\Delta \delta$ $\mathrm{D}_{\text {corr }}$ corresponds to the temporal deviation from the presentday deuterium content, corrected for past variations in the global ocean using the $\delta^{18} \mathrm{O}$ record derived from the benthic foraminifera stacks (Lisiecki and Raymo, 2005). The latter is itself corrected for deep-water temperature effects. $\Delta \delta \mathrm{D}_{\text {smo }}$ is a 50 -yr average of $\Delta \delta \mathrm{D}_{\text {corr }}$ and $\alpha$ represents the slope of the present-day spatial isotopic thermometer. $\beta$ is a coefficient defining the glacial-interglacial amplitude of accumulation changes.

The model contains several poorly known parameters (namely $\alpha, \beta$, a parameter $p$ determining the vertical profile for deformation (Liboutry and Ritz, 1978), and past elevation changes, $\Delta H$ ) and also requires input information regarding current conditions prevailing at the site (see Table 4). Unknown parameters are determined here by carrying several simulations until the best overall fit with the independent age markers is obtained.
Table 5. Estimated elevation changes (positive numbers indicate an increase) in the TALDICE area between 0 and $30 \mathrm{kyr}$ BP. Error bars are estimated from literature descriptions (Stenni et al., 2011).

\begin{tabular}{rc}
\hline age (kyr BP) & Elevation change $(\mathrm{m})$ \\
\hline 0 & 0 \\
7 & $0 \pm 20$ \\
10 & $100 \pm 50$ \\
12.7 & $170 \pm 50$ \\
16 & $170 \pm 20$ \\
19 & $100 \pm 50$ \\
25 & $20 \pm 50$ \\
30 & $0 \pm 50$ \\
\hline
\end{tabular}

\subsection{Elevation changes at Talos Dome}

The thinning function at TALDICE could have been affected by past elevation changes at the dome. It is thus important to estimate and take these changes into account in the ice flow simulations. Constraints on past elevation changes, $\Delta \mathrm{H}$, in the Talos Dome area are available since the last deglaciation; they are summarized in Table 5. Geomorphological studies carried through the Outback Nunataks range and in the Ross Sea sector revealed past glacier tracks, suggesting a maximum $\Delta \mathrm{H}$ of $170 \pm 20 \mathrm{~m}$ reached between 19 and $13 \mathrm{kyr}$ BP. Elevation changes during the Last Glacial Maximum (LGM) have been triggered by the progression of the grounding line up to the continental margin in response to the glacial sea level lowering (Anderson et al., 2002). The maximum elevation change is consistent with analyses of moraine deposits in the upper part of Rennick Glacier (Meneghel et al., 1999), a few tens of $\mathrm{km}$ east of Talos Dome. It suggests an increase of the glacier thickness by about $200 \mathrm{~m}$ during the first part of the last termination. 

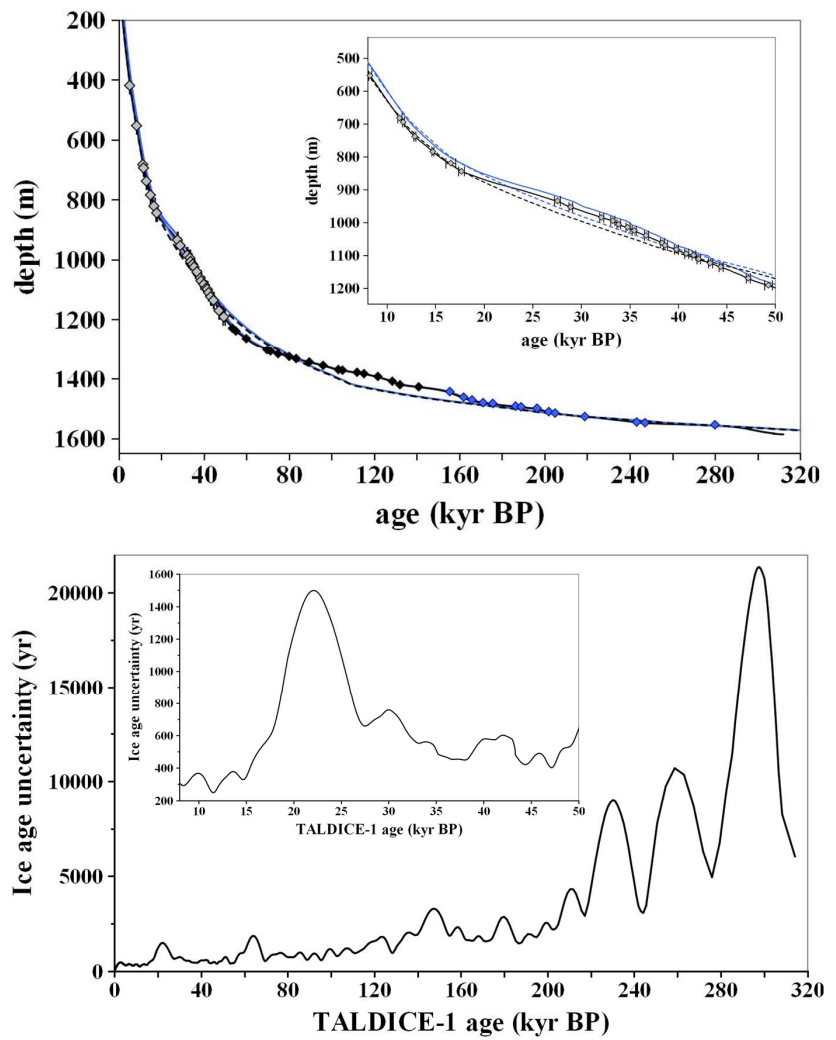

Fig. 2. Top: TALDICE-1 age/depth relationship for the ice (blue lines) and for the gas (black lines), from the a priori glaciological model (dashed lines), and after applying the inverse method (continuous lines), with a zoom on the period between 8 and $50 \mathrm{kyr} \mathrm{BP}$; Bottom: uncertainty associated with the chronology deduced from the inverse method and zoomed between 8 and $50 \mathrm{kyr}$ BP.

The increased dome elevation during part of the deglaciation resulted from the increase of accumulation rate. We suggest that the dome started to lower its elevation when the grounding line retreated from its LGM position between 14.3 and $12 \mathrm{kyr}$ BP (Anderson et al., 2002). Mackintosh et al. (2007) measured exposure ages of mountains dipsticks across the Framnes Moutains in Mac Robertson Land in East Antarctica. They concluded to a maximum thickness of the East Antarctic ice sheet around $13 \mathrm{kyr}$ BP. Studies performed in other coastal Antarctic areas at the onset of the Holocene around $10 \mathrm{kyr}$ BP, such as moraine dating in the Mary Byrd Land region (Ackert et al., 1999), suggest that $\Delta \mathrm{H}$ was still $100 \pm 50 \mathrm{~m}$ higher than today. We thus extend these conclusions to the case of Talos Dome as well. Radiochronological measurements on penguin guano, shells and seal skin (Baroni and Hall, 2004) suggest that the retreat of the East Antarctic ice sheet margin reached Terra Nova Bay shortly before $7 \mathrm{kyr}$ BP. Such evolution of the dome elevation in the course of the last deglaciation and the early Holocene contrasts with the ice sheet elevation changes on the East Antarctic plateau, where the altitude was lower during the LGM, due to the dominant effect of reduced glacial accumulation rates (Ritz et al., 2001). Observations of glacial geology and ${ }^{14} \mathrm{C}$ dating point out that the Ross Ice Sheet started to grow at Mc Murdo Sound around $30 \mathrm{kyr}$ BP (Baroni, C., personal communication, 2010). We thus make the assumption that the present dome elevation is similar to that $30 \mathrm{kyr} \mathrm{BP}$ and went through an intermediate maximum around $16 \mathrm{kyr} \mathrm{BP}$.

$\triangle \mathrm{H}$ at TALDICE is incorporated as input information in the 1-D ice flow model: water isotopic data are corrected for elevation changes before being used to derive past temperature and accumulation rate (with a gradient of $1.3 \%$ o $100 \mathrm{~m}$ of elevation change).

\subsection{Results obtained with the 1-D ice flow model}

The resulting a priori chronology appears in good agreement with some age markers, while differences remain with others (Fig. 2). The use of a glaciological model tends to smooth the depth-age relationship, leading to disagreements of up to $30 \mathrm{kyr}$ with some of the tie points older than $140 \mathrm{kyr}$ BP.

Due to numerous poorly-defined parameters and the simple description of ice flow, which does not account for the effect of anisotropy on rheology, the 1-D model is not able to describe past migrations of the dome summit or changes of its lateral limits which induce errors in the thinning function scenario. The model also neglects the fact that relationships between accumulation rate, temperature and water isotopic data could have been different in the past (Masson-Delmotte et al., 2006; Stenni et al., 2001).

\section{TALDICE-1 age scale based on an inverse method}

\subsection{Principles}

The inverse method used here to improve the glaciological model output is a probabilistic inverse approach based on a Bayesian inference. It attempts to find the best compromise between the a priori ice flow model scenario and chronological information from tie points (Lemieux-Dudon et al., 2009). It optimizes the three key glaciological entities that vary in the past: the accumulation rate, the total thinning function, and the CODIE.

The probabilistic combination of uncertainties of the model and of the tie points also enables to estimate confidence intervals on the new dating.

\subsection{Input parameters}

In addition to the background scenario (based on ice flow and snow densification simulations) a background error covariance matrix, which accounts for the uncertainties on the background dating scenario must be assessed in order to run the inverse method. In this study, we made the following assumptions: (i) no error correlation between the accumulation rate and the thinning function, as argued by Parrenin 
et al. (2007b) who show that the total thinning function is only weakly sensitive to accumulation changes; (ii) no error correlation between the accumulation rate and CODIE (the relationship between the CODIE and climatic parameters is complex, non-linear and with opposite effects of temperature and accumulation rate; e.g., Landais et al., 2006). The resulting error covariance matrix is therefore a diagonal block with three sub-matrices respectively associated to the three glaciological entities (thinning, accumulation and CODIE). These sub-matrices are fully defined by setting a standard deviation vector and a correlation matrix.

The standard deviation and correlation profiles were chosen of the same order of magnitude as proposed in LemieuxDudon et al. (2009, 2010). A constant standard deviation with depth (set to $40 \%$ ) is assessed for the accumulation rate and the CODIE (more precisely to the logarithm of these quantities because errors are assumed to be lognormally distributed). A growing function with depth is chosen for the thinning function (Lemieux-Dudon, 2009, 2010). The correlation profiles are normalized Gaussian functions with a correlation length parameter. The latter parameter is in time unit for the accumulation and CODIE and set to $4000 \mathrm{yr}$. It is in depth unit for the thinning function and set to $50 \mathrm{~m}$. Further statistical analysis shall be performed to better constrain these parameters, but this is beyond the scope of the paper. A posteriori controls on the background settings can be conducted by testing the new chronology against independent paleoclimatic data (see Sect. 5.1.3).

\section{Results and discussion}

\subsection{TALDICE ice and gas chronologies and confidence intervals}

\subsubsection{The new gas and ice age scales}

Figure 2 shows the age/depth relationship at TALDICE according to the a priori glaciological model and after using the inverse method. They are both compared to age markers, and the confidence interval on the ice chronology calculated by the inverse method is also provided.

The TALDICE-1 chronology provides a very good agreement with all age markers. As previously observed (Lemieux-Dudon et al., 2010) the relative chronological uncertainty decreases at the location of age markers and increases during periods where few or no age markers are available. In addition, the uncertainty increases with depth.

The TALDICE-1 age scale provides an uncertainty of $\sim 300 \mathrm{yr}$ over the last deglaciation and is lower than $600 \mathrm{yr}$ during the D/O events of MIS 3. The relative uncertainty reaches $2 \mathrm{kyr}$ at the MIS5.5 onset. By comparison, the uncertainty of the EDC3 and EDML1 time scales (Parrenin et al., 2007a; Ruth et al., 2007) over the last deglaciation, the MIS 3 period and the MIS 5.5 onset are estimated to be $0.4 \mathrm{kyr}$,

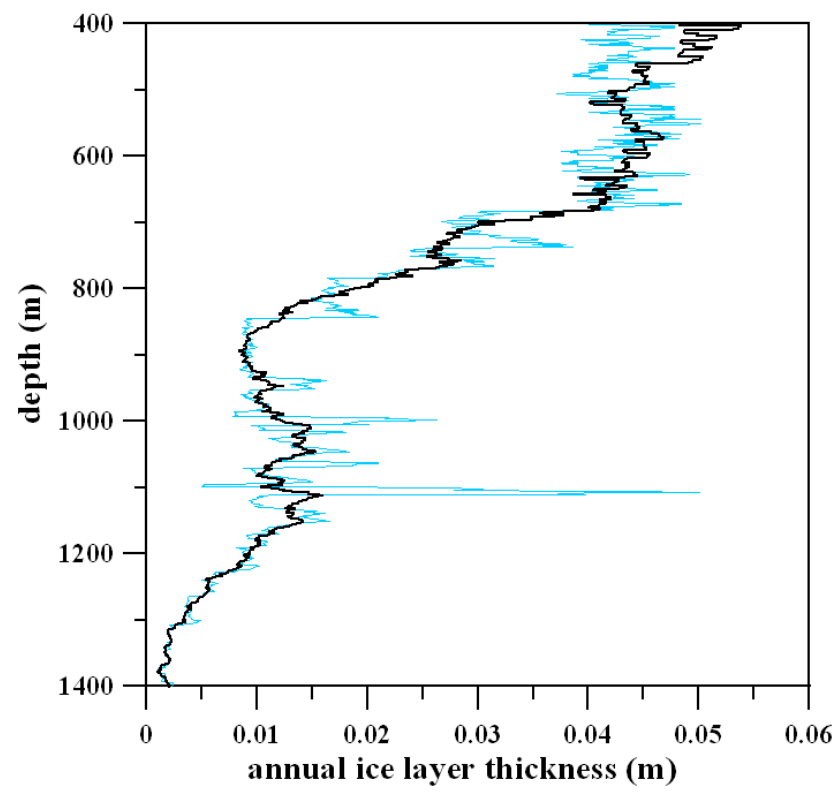

Fig. 3. Evolution with depth of the annual ice layer thickness along the TALDICE core deduced from a simple interpolation of age between gas stratigraphic markers (blue line) and deduced from the inverse method (black line).

$1.5 \mathrm{kyr}$ and $3 \mathrm{kyr}$, respectively. The relatively small uncertainty in the TALDICE-1 chronology during MIS 3 enables us to investigate in detail the timing of the millennial-scale climatic events throughout the last climatic cycle.

For periods older than the last interglacial MIS5.5, the errors associated with tie points becomes considerably larger than for the younger TALDICE ice, due to the slow water isotopic variations and relatively poor time resolution of the TALDICE $\delta^{18} \mathrm{O}$ record; the chronological uncertainty remains lower than $3 \mathrm{kyr}$ down to $205 \mathrm{kyr} \mathrm{BP}$, and then increases up to $\sim 30 \mathrm{kyr}$ yr for the oldest part of the record.

In order to highlight the scientific interest of using the inverse method instead of a simple interpolation between tie points (as often done so far, e.g., Blunier et al., 2007), we show in Fig. 3 the annual layer thickness obtained with the inverse method and with the interpolation. The second method generates unrealistic changes of layer thicknesses, due to the abrupt squeezing-stretching required between tie points. In contrary, the inverse method provides a much smoother layer thickness evolution, reflecting the tuning of glaciological parameters using a standard deviation and a correlation length.

\subsubsection{Corrections applied to the background scenario}

Figure 4 shows the ratio between the accumulation rate, thinning rate and CODIE values deduced from the inverse method and those estimated by the background scenario, focusing on the last $50 \mathrm{kyr}$ where age markers are more frequent. 


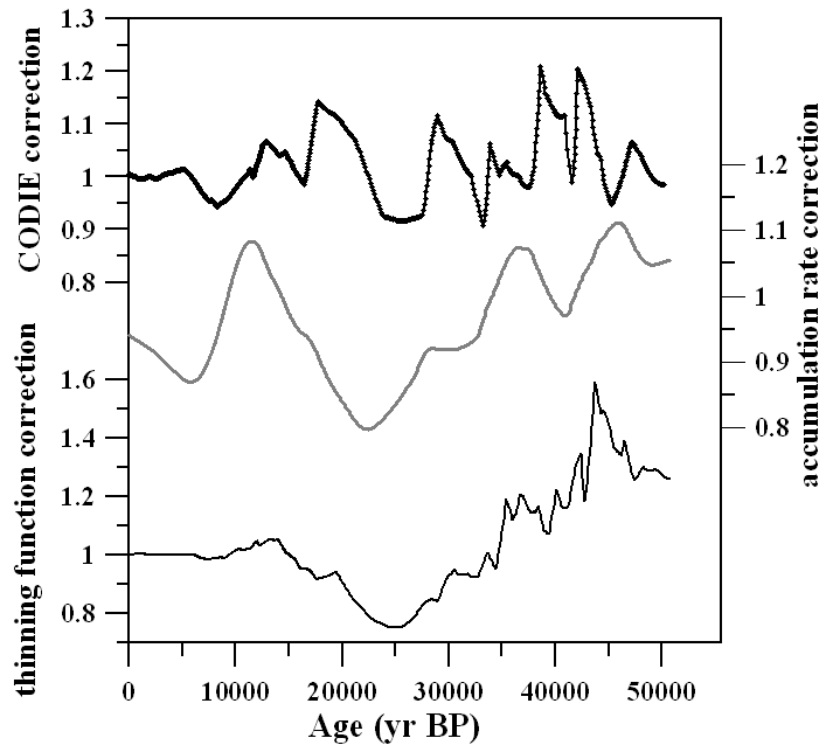

Fig. 4. Ratio between a posteriori and a priori values of glaciological entities plotted against the TALDICE-1 age scale: From top to bottom: CODIE (black line with symbols) accumulation rate (grey line), and thinning function (black line).

Corrections applied to the accumulation rate usually remain lower than the $\pm 20 \%$ error margin usually considered for the accumulation rate deduced from isotopic data (Blunier et al., 2007; Huber et al., 2006). Only during the MIS 2 period the inverse method requires a decrease of $20 \%$ compared to the initial accumulation rate.

Corrections applied to the CODIE do not exceed $16 \%$, and are consistent with typical uncertainties associated with modeled and measured close-off depth (Goujon et al., 2003; Landais et al., 2006).

The correction applied to the modeled thinning function remains below $5 \%$ for the last $16 \mathrm{kyr}$. It then increases to about $22 \%$ at $25 \mathrm{kyr}$ BP, followed by a decrease and a constant level below $15 \%$ until around $40 \mathrm{kyr}$ BP where small successive $\mathrm{D} / \mathrm{O}$ events occur. These tie points lead to larger changes in the thinning function deduced by the inverse method.

\subsubsection{A posteriori evaluation of the TALDICE-1 age scale}

\section{A posteriori evaluation with a firn densification model}

The CODIE determined with the inverse method can be evaluated a posteriori by transforming it into a $\Delta$ age and by comparing it with the output of the firn densification model of Goujon et al. (2003). The latter calculates the CODIE and $\triangle$ age using the temperature and accumulation rate scenarios from the inverse model. Indeed surface temperature and accumulation rate are known to be the two main parameters controlling firn densification (Schwander et al., 1997).

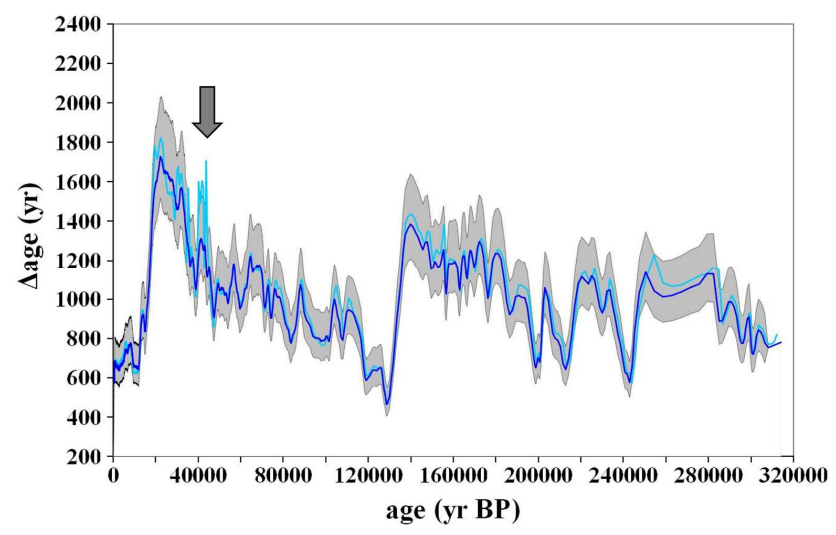

Fig. 5. $\triangle$ age evolution on the TALDICE-1 age scale, calculated by the inverse model (light blue line) and by the firn densification model (dark blue line). The grey shade represents the error interval based on accumulation rate uncertainties of $\pm 20 \%$. The maximum difference recorded between $\Delta$ age estimates from the inverse method and from the firn densification model is pointed by the arrow: it occurs around $40 \mathrm{kyr} \mathrm{BP}$ and reaches $400 \mathrm{yr}$. The difference remains below $\pm 200 \mathrm{yr}$ for other times.

The $\Delta$ age deduced from the CODIE of the inverse method and the one calculated by the firn densification model agree very well all along the core (Fig. 5). $\Delta$ ages provided by the densification model when we vary accumulation rates from the inversion in a $\pm 20 \%$ range fully bracket the inverse model-based $\Delta$ age. The mean difference between both gas chronologies amounts to only $16 \mathrm{yr}$. However, differences reach up to $450 \mathrm{yr}$ over D/O events \#9, 10 and 11 . This reflects the difficulty to define accurate $\mathrm{CH}_{4}$ tie points for these small events.

\section{A posteriori evaluation using $\delta^{18} \mathrm{O}$ of molecular oxygen}

As in the case of atmospheric $\mathrm{CH}_{4}$, the isotopic composition of molecular oxygen in the atmosphere $\left(\delta^{18} \mathrm{O}_{\mathrm{atm}}\right)$ is globally homogeneous and shows changes associated with climate variations (Bender et al., 1994; Sowers et al., 1991). It can thus complement $\mathrm{CH}_{4}$ tie points, especially during periods of time when the atmospheric $\mathrm{CH}_{4}$ mixing ratio does not vary much in the atmosphere. Down to $50 \mathrm{kyr}$ BP we choose to compare TALDICE $\delta^{18} \mathrm{O}_{\mathrm{atm}}$ to the EDML record on the new EDML age scale (Lemieux-Dudon et al., 2010), both chronologies being thus tied to the GICC05 chronology (Fig. 6). For older ages, where TALDICE methane is synchronized to the EDC one on the EDC3 chronology, we compare TALDICE and EDML $\delta^{18} \mathrm{O}_{\text {atm }}$ records on the EDML1 age scale which is tied to the EDC3 one (Ruth et al., 2007), and to the Vostok $\delta^{18} \mathrm{O}_{\text {atm }}$ record (Petit et al., 1999) which has been previously put on the EDC3 age scale (Loulergue et al., 2008). New EDML $\delta^{18} \mathrm{O}_{\text {atm }}$ measurements before $80 \mathrm{kyr}$ BP were performed at LSCE with the same analytical method. 


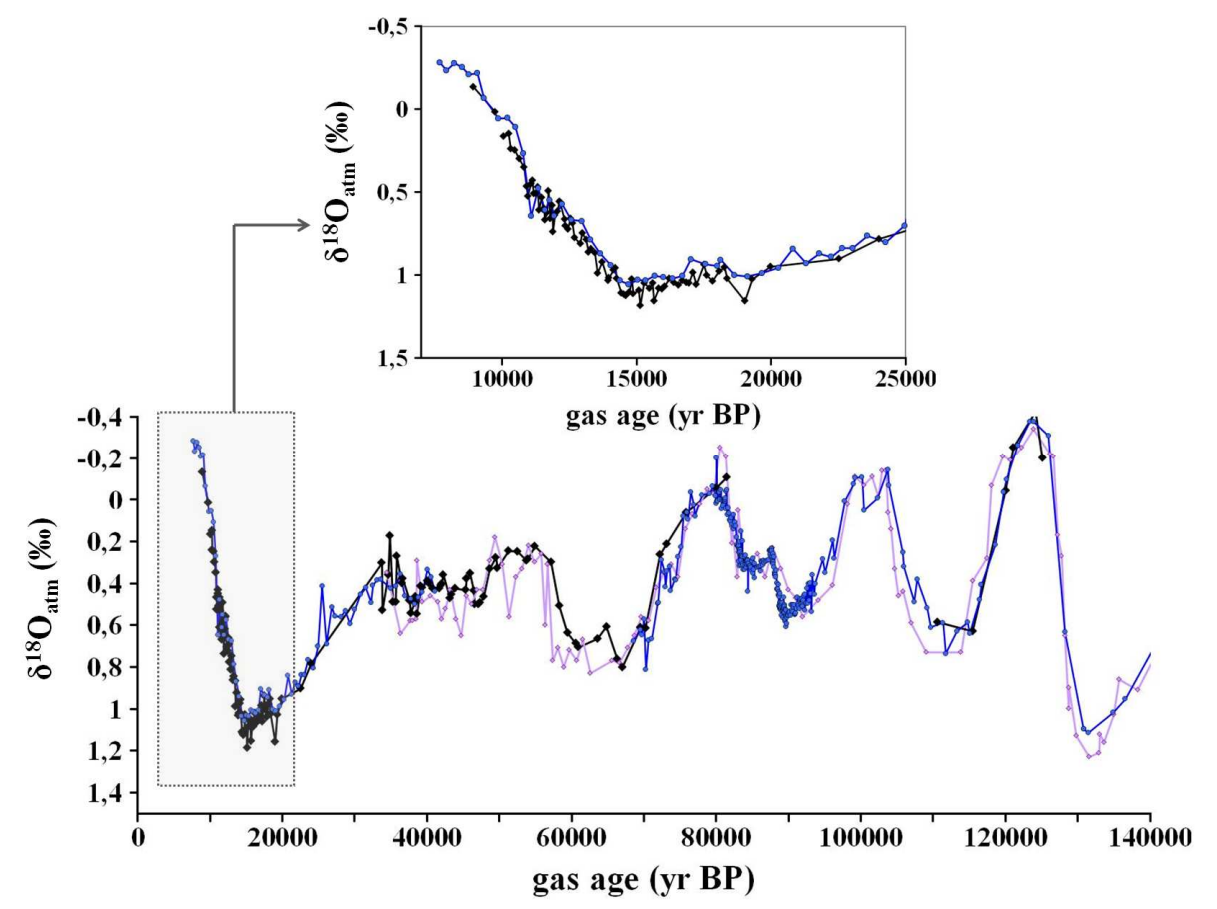

Fig. 6. $\delta^{18} \mathrm{O}_{\mathrm{atm}}$ measured along the TALDICE ice core (black line and symbols) on the TALDICE-1 age scale, compared with its counterparts from EDML (blue line with rounded symbols; Capron et al., 2010) and Vostok (purple line; Petit et al., 1999). Inside frame: zoom on the LGM and the last deglaciation.

The three $\delta^{18} \mathrm{O}_{\text {atm }}$ records appear in very good agreement (Fig. 6). We particularly focused our measurements on the deglaciation period, where we observe an extremely good fit between EDML and TALDICE records. Those observations strengthen our confidence on the choice of the preliminary age markers.

The few points measured between 60 and $85 \mathrm{kyr} \mathrm{BP}$ and after $100 \mathrm{kyr}$ BP enable to catch the sharp $\delta^{18} \mathrm{O}_{\text {atm }}$ transition between 70 and $80 \mathrm{kyr}$ BP, taking place at a time of reduced $\mathrm{CH}_{4}$ variations. It reasonably confirms that the right stadials and interstadials have been matched together.

\subsection{How physically realistic are the glaciological parameters resulting from the inverse model?}

\subsubsection{Accumulation rate reconstruction}

\section{Comparison with the water isotopic signal}

Overall, the accumulation rate calculated by the inverse method over the full TALDICE time scale is very close to the one deduced from the water isotopes, as can be seen in Fig. 7. It gives confidence that the standard relationship expected between the accumulation rate and isotopic data is also valid at Talos Dome on long time scales (Frezzotti et al., 2004, 2007; Magand et al., 2004). Still, a difference of $25 \%$ is observed around $23 \mathrm{kyr}$ BP (Fig. 7). The amplitude of the last glacial-interglacial accumulation rate changes thus appears slightly more pronounced with the scenario from the inverse method or, conversely, underestimated with the classical approach. These differences could be partly explained by the fact that the 1-D model is not able to simulate whether relationships between accumulation rate/temperature and isotopic data have been different in the past (Masson-Delmotte et al., 2006; Stenni et al., 2001). This discrepancy occurs in the $18-30 \mathrm{ka}$ interval, at a time when the simple Greenland $\delta^{18} \mathrm{O}$-accumulation relationship also breaks down (Svensson et al., 2006).

As previously explained, the link between the accumulation rate and the water isotopic signal is represented in the models by the parameter $\beta$, which consists of a constant value in the classical approach. However the inverse method requires a $\beta$ value varying in time, around a mean value of 0.0198 associated with a correlation coefficient $R^{2}=0.93$ between accumulation rate and deuterium data. We add to the Fig. 7 the accumulation rate calculated for a constant $\beta=0.0198$. It seems that the inverse accumulation rate mainly differs from this relationship in the period ranging between the AIM1 and the Early Holocene, showing higher values, whereas it differs from the direct model accumulation rate during LGM low values.

The large accumulation rate decrease during the LGM, and to a lesser extent during MIS 6, could reflect the sensitivity of this coastal site to changes of moisture source due 


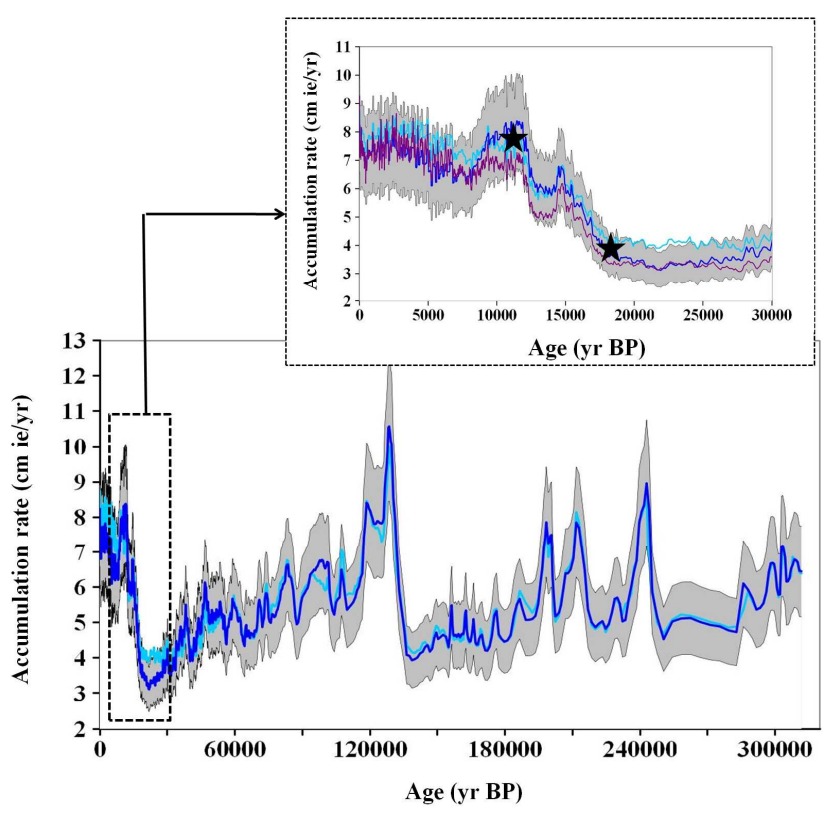

Fig. 7. Accumulation rate history deduced from the water isotopic profile corrected from elevation changes (light blue line) and after adjustment by the inverse method (dark blue line). The grey area represents the error interval for an accumulation rate varying by $\pm 20 \%$ around the value deduced from the inverse method. Inside frame: zoom over the last deglaciation period. We add the ${ }^{10} \mathrm{Be}$ constraints for Holocene and LGM periods (stars); it is set to match the average Early Holocene accumulation rate deduced from the inverse and direct reconstructions, and then shown with the ratio calculated between Holocene and LGM periods as explained in the second subsection of Sect. 5.2.1. We also plot the accumulation rate calculated by the traditional isotopic equation for a value of $\beta=0.0198$ (purple line), after having corrected the water isotopic data from elevation changes.

to sea ice extent and presence of an ice sheet in the Ross sea embayment, both possibly affecting snow precipitation linked to cyclonic activity and wind-scouring. Indeed, radar layer studies have shown that the LGM snow accumulation became nearly negligible at Taylor Dome (also in the Ross sea embayment), probably in response to changes in storm tracks (Morse et al., 1998, 2007). Talos Dome is influenced by moisture originating mainly from the Indian (around 50\%) and in a lesser extent from the Pacific/Ross Sea (30\%) sectors of the Southern Ocean (Scarchilli et al., 2010). The snowfalls originating from the Pacific Ocean reach Talos Dome after crossing the Ross Sea, where extensive presence of sea ice occurs also during summer time. During the LGM and most of the deglaciation, the presence of the Ross Ice Sheet extending up to the continental margin could have contributed to dry the air masses coming from the Ross Sea area. The same phenomenon could explain the different ratio between accumulation and water isotopes between the LGM and the Holocene.

\section{A posteriori control with ${ }^{10} \mathrm{Be}$ data}

The cosmogenic isotope Beryllium-10 $\left({ }^{10} \mathrm{Be}\right)$ signal in ice cores is influenced by changes in its production, deposition processes and snow accumulation. During a deglaciation, the snow accumulation drastically changes and at first order, ${ }^{10} \mathrm{Be}$ concentration can be used to constrain it. Previous studies have shown that ${ }^{10} \mathrm{Be}$ is mostly dry deposited on the East Antarctic plateau, enabling to directly connect ${ }^{10} \mathrm{Be}$ concentrations in the ice $\left[{ }^{10} \mathrm{Be}\right]$ with the snow accumulation rate (Delmas, 1992; Raisbeck and Yiou, 1985), adding a constant term for the wet deposition effect.

${ }^{10} \mathrm{Be}$ measurements have been performed on TALDICE ice covering the last deglaciation on the new Accelerator Mass Spectrometer, ASTER, installed at CEREGE. They show a near-doubling of $\left[{ }^{10} \mathrm{Be}\right]$ in LGM ice compared with the Holocene one, similar to the Vostok Antarctic site (Raisbeck et al., 1992) or to the GISP2 and GRIP Greenland sites (Finkel and Nishiizumi, 1997; Raisbeck et al., 1992). ${ }^{10} \mathrm{Be}$ concentration and snow accumulation rate are inversely correlated. Calculating the ratios $\left[{ }^{10} \mathrm{Be}\right]_{\mathrm{AIM} 1} /\left[{ }^{10} \mathrm{Be}\right]_{\text {Holocene }}$ and $\left[{ }^{10} \mathrm{Be}\right]_{\mathrm{LGM}} /\left[{ }^{10} \mathrm{Be}\right]_{\text {Holocene, }}$ we obtain 1.23 and 1.82 , respectively. The former is similar to the Holocene/AIM1 ratio of accumulation rate deduced from the inverse method. On the other hand the inverse method provides a Holocene/LGM accumulation rate ratio of 2.20 , whereas the ratio deduced from water isotopes is 1.80 (Fig. 7). This means that either the more reduced accumulation rate during the LGM deduced from the inverse method is incorrect (i.e., the method gives too much weight to accumulation rate changes relative to thinning function changes) or that parameters other than accumulation rate, such as cosmogenic isotope production, wet versus dry deposition changes and/or, dust and aerosol variations or atmospheric transport, also modulated the TALDICE LGM/Holocene $\left[{ }^{10} \mathrm{Be}\right]$ values. At the moment we have no firm argument favoring either of these possibilities.

\subsubsection{Thinning function}

Broadly speaking, the a priori ice-flow model calculations provide a thinning function in good agreement with the one deduced by the inverse method. However the dome may have moved slightly through time (Urbini et al., 2008), generating a different deformation regime than uniaxial compression over a certain depth range in the ice, and some changes in deformation history between ice layers. Thus local differences between the ice-flow and inverse thinning function can be expected and are indeed observed.

There is no direct proxy to quantify the thinning function with depth. Some physical properties of ice, e.g. the c-axis orientation (fabric) and the crystal size, allow one to qualitatively assess changes in the deformation regime. They could reflect and/or generate changes in the local thinning, in association with changes in ice properties. 
The c-axis distribution of crystals (the fabric) reflects their orientation and is known to be a consequence of the strainrate history experienced by ice during transport from the ice sheet surface (Castelnau and Duval, 1994; Durand et al., 2007). C-axes rotate during the deformation towards the main direction of compression and away from the tensional direction (Van der Veen and Whillans, 1994). Consequently, the resulted anisotropy of the ice will affect the flow of ice (Gagliardini and Meyssonnier, 2000; Mangeney et al., 1997; Pettit et al., 2007). We can thus qualitatively compare the fabric evolution with the reconstructed thinning function, to look for possibly common patterns.

Thin sections were extracted from the side part of the TALDICE core, vertically. The fabrics (crystal orientations) were obtained using an automatic ice fabric analyzer (Russell-Head and Wilson, 2001) which provides caxis orientation point every $43 \mu \mathrm{m}$ over the thin section $\left(80 \times 11 \mathrm{~mm}^{2}\right)$.

The c-axis orientation data are represented by the orientation tensor $a^{(2)}$ (Woodcock, 1977; Durand et al., 2006) . The eigenvalues of this orientation tensor are used to express the evolution of the c-axis orientation with depth (Durand et al., 2006; Montagnat, 2011). The evolution of the higher eigenvalues $a_{1}^{(2)}$, expresses the progressive fabric clustering toward the vertical direction. A value of 1 means that all crystal c-axes are vertically oriented and a value of $1 / 3$ would correspond to an isotropic fabric. The $a_{1}^{(2)}$ evolution with depth is plotted in Fig. 8, together with the direct and inverse modeled thinning functions.

Several interesting features show up in the common trends between fabric evolution and the modeled thinning functions:

- Between 750-950 m (11.5-30.3 kyr BP) the fabric evolution shows a change of slope with a clear increase in the rate of fabric clustering. It corresponds to the deglaciation period from MIS 2 to the Early Holocene, encompassing the LGM period. As suggested by Patterson (1991) and Cuffey et al. (2000), the transition between glacial to interglacial ice could be related to a change in ice viscosity. This change in viscosity can result in a positive feedback with glacial ice layer easier to shear, and shear reinforcing the fabric concentration (Durand et al., 2007). The change of slope observed in the fabric evolution thus suggests that the uniaxial compression deformation regime is combined with shearing, making deformation stronger in this layer. This change goes together with a change in the inverse thinning function.

- Between 950-1150m (40.3-46.6 kyr) fabric data remain relatively constant. This could indicate that those successive layers have followed different deformation histories and thus different trajectories in the ice sheet. This could result from a displacement of the ice dome through time with associated increased development of

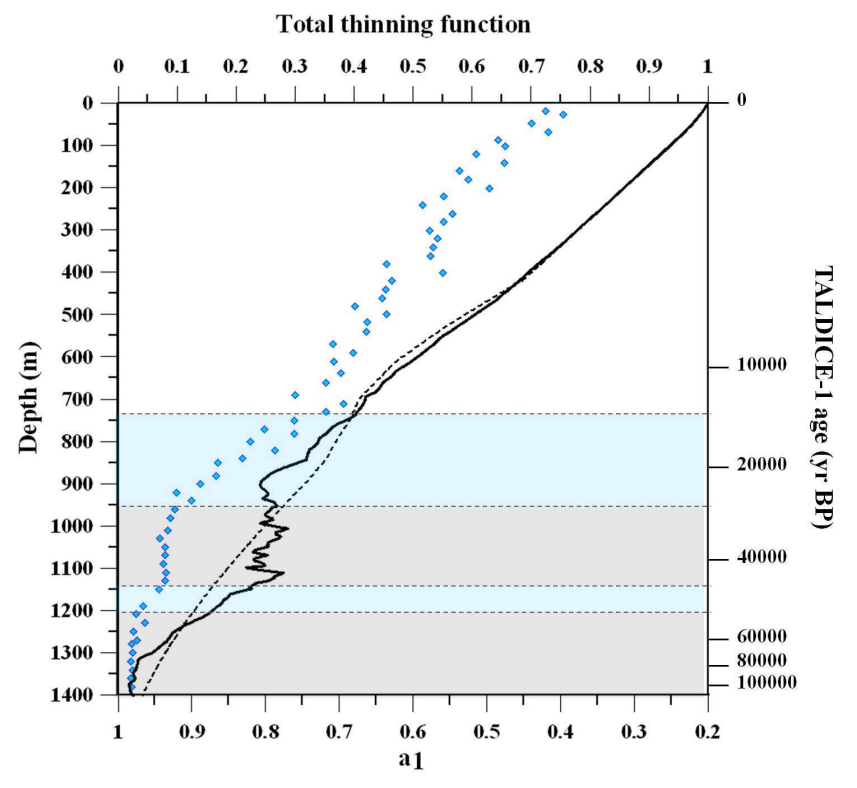

Fig. 8. Comparison of thinning functions deduced from the a priori ice-flow model (black dashed line) and by the inverse model (black continuous line). They are shown together with the eigenvalues $a_{1}$ of the second order orientation tensor measured along the TALDICE ice core (blue diamonds). Grey and blue shades underline changes of slope in the fabric evolution.

shear stresses (Castelnau et al., 1998). Such combinations of stress configuration and compatible fabric lead to reduced strain rates in compression. This observation goes together with the near absence of thinning estimated by the inverse model for this depth interval.

- Between 1150-1200 m (46.6-51.2 kyr) the fabric data show an abrupt slope shift towards higher values. This change of slope appears synchronous with the resumption of the thinning rate evolution which gradually decreases with depth.

- Between 1200-1400m (51.2-124.8 kyr BP), no more evolution is observed in the fabric concentration that has reached its maximum level, nor in the thinning rate trend that gradually decreases toward an expected minimum in the deeper zone.

In summary the comparison between fabric evolution, inverse thinning function and direct thinning function reveals that depth ranges where the fabric evolution do not follow a regular uniaxal compression regime correspond to depth ranges where the inverse thinning function departs from the direct one. The fabric evolution clearly depicts shear stress in the ice flow along the Talos Dome ice core. A simplified 1-D flow model which only takes into account uniaxial compression strain along the core cannot well represent the impact of such changes of the stress regime on the ice flow ice. On the other hand the inverse model is able to integrate 
well some of the variations in the deformation conditions and their expected impact on the local layer thinning.

Discussing the exact mechanisms behind the fabric evolution observed along the Talos Dome core is the subject of another paper (Montagnat et al., 2011). This step will provide other constraints to the inverse method to directly integrate changes in ice viscosity and flow conditions in the dating exercise.

\section{Conclusions}

We have built the first official dating - called TALDICE-1of the new coastal ice core drilled at Talos Dome in Antarctica. Its quality comes from the use of $\mathrm{CH}_{4}$ tie points, the implementation of a new inverse method for dating ice cores, and the availability of a posteriori information. Although this chronology will evolve in the future, in particular for periods of time older than $50 \mathrm{kyr}$ BP and during the Holocene, with the addition of new control points and with better constraints on accumulation rate changes and on the thinning of ice layers with depth, it already provides us a solid background dating. It gives confidence in the conclusions raised from this new deep ice core, in terms of phasing between Greenland, the East Antarctic plateau and Talos Dome during the last deglaciation (Stenni et al., 2011) and during MIS 3.

The TALDICE-1 age scale provides an age uncertainty relative to the GICC05 age scale of about $300 \mathrm{yr}$ for the ice record covering the last deglaciation; this uncertainty remains lower than $600 \mathrm{yr}$ back to $50 \mathrm{kyr} \mathrm{BP}$ during the millennial-scale events which occurred during the last glacial period. The resulting gas and ice chronologies are consistent with $\Delta$ age estimated by a firn densification model (Goujon et al., 2003), using the input climatic conditions resulting from the inverse method. Such consistency is usually a real challenge for ice core dating (Loulergue et al., 2007) and makes the use of the TALDICE-1 chronology a clear asset for further climatic investigations.

The next steps to improve the TALDICE age scale should include higher resolution records notably over the deepest part of the core (below $1420 \mathrm{~m}$ ), and the use of the ${ }^{10} \mathrm{Be}$ peak associated with the Laschamp event at $41.5 \mathrm{kyr} \mathrm{BP}$, which will provide a firm marker of TALDICE $\triangle$ age under glacial conditions (Loulergue et al., 2007).

Eventually proxies currently used as a posteriori information, like the $\delta^{18} \mathrm{O}_{\text {atm }}$ profile or dust and sulphate contents, could be later directly used as input chronological information in the inverse method, when additional data connected to the ice core age will be available during periods of low methane variations.

Acknowledgements. Talos Dome Ice core Project (TALDICE), a joint European program led by Italy, is funded by national contributions from Italy, France, Germany, Switzerland and the United Kingdom. The main logistical support was provided by PNRA at Talos Dome. We thank the logistic and drilling TALDICE team for their efficiency over each drilling season. Funding support for the dating work was provided by the Institut National des Sciences de l'Univers (INSU) through its program LEFE. We thank Mélanie Baroni from CEREGE for providing data and interpretation of ${ }^{10} \mathrm{Be}$, Mirko Severi for providing sulfate data and Barbara Delmonte for providing dust data. Thanks also to Frédéric Prié and Bénédicte Minster for their help during isotopic measurements at LSCE, Saclay. We are deeply indebted to our late colleague Jean-Marc Barnola for his help concerning the use of the firn densification model. We thank the two anonymous reviewers for their very useful comments and suggestions on the first draft. This is TALDICE publication no 11 .

Edited by: T. van Ommen

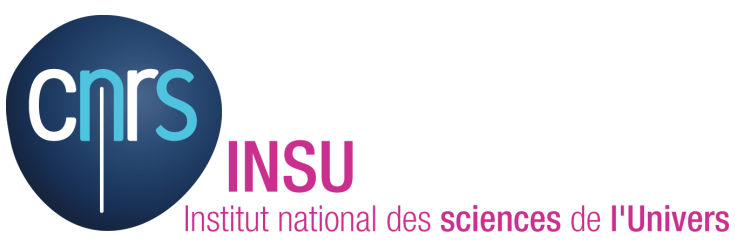

The publication of this article is financed by CNRS-INSU.

\section{References}

Ackert, R. P., Barclay, D., Borns, H., Calkin, P., Kurz, M., Fastook, J., and Steig, E.: Measurements of Past Ice Sheet Elevations in Interior West Antarctica, Science, 286(5438), 276-280, doi:10.1126/science.286.5438.276, 1999.

Andersen, K. K., Svensson, A., Johnsen, S. J., Rasmussen, S. O., Bigler, M., Röthlisberger, R., Ruth, U., Siggaard-Andersen, M. L., Steffensen, J. P., and Dahl-Jensen, D.: The Greenland Ice Core Chronology 2005, 15-42 ka. Part 1: constructing the time scale, Quaternary Sci. Rev., 25(23-24), 3246-3257, 2006.

Anderson, J. B., Shipp, S. S., Lowe, A. L., Wellner, J. S., and Mosola, A. B.: The Antarctic Ice Sheet during the Last Glacial Maximum and its subsequent retreat history: a review, Quaternary Sci. Rev., 21(1-3), 49-70, 2002.

Arnaud, L., Barnola, J. M., and Duval, P.: Physical modeling of the densification of snow/firn and ice in the upper part of polar ice sheets, in Physics of Ice Core Records, 285-305, T. Hondoh; Hokkaido Univ. Press, Sapporo, Japan, 2000.

Baroni, C. and Hall, B. L.: A new Holocene relative sea-level curve for Terra Nova Bay, Victoria Land, Antarctica, J. Quaternary Sci., 19(4), 377-396, doi:10.1002/jqs.825, 2004.

Bender, M., Sowers, T., and Labeyrie, L.: The Dole Effect and its variations during the last 130000 years as measured in the Vostok Ice Core, Global Biogeochem. Cy., 8(3), 363-376, doi:199410.1029/94GB00724, 1994.

Blunier, T., Schwander, J., Stauffer, B., Stocker, T., Dällenbach, A., Indermühle, A., Tschumi, J., Chappellaz, J., Raynaud, D., and Barnola, J. M.: Timing of the Antarctic cold reversal and the atmospheric $\mathrm{CO}_{2}$ increase with respect to the Younger Dryas Event, Geophys. Res. Lett., 24(21), 2683-2686, doi:199710.1029/97GL02658, 1997.

Blunier, T., Chappellaz, J., Schwander, J., Dällenbach, A., Stauffer, B., Stocker, T. F., Raynaud, D., Jouzel, J., Clausen, H. B., Hammer, C. U., and Johnsen, S. J.: Asynchrony of Antarctic and 
Greenland climate change during the last glacial period, Nature, 394(6695), 739-743, doi:10.1038/29447, 1998.

Blunier, T. and Brook, E. J.: Timing of millennial-scale climate change in Antarctica and Greenland during the last glacial period, Science, 291(5501), 109-112, 2001.

Blunier, T., Spahni, R., Barnola, J.-M., Chappellaz, J., Loulergue, L., and Schwander, J.: Synchronization of ice core records via atmospheric gases, Clim. Past, 3, 325-330, doi:10.5194/cp-3-3252007, 2007.

Brook, E. J., Sowers, T., and Orchardo, J.: Rapid Variations in Atmospheric Methane Concentration during the Past 110000 Years, Science, 273(5278), 1087-1091, doi:10.1126/science.273.5278.1087, 1996.

Brook, E. J., White, J. W., Schilla, A. S., Bender, M. L., Barnett, B., Severinghaus, J. P., Taylor, K. C., Alley, R. B., and Steig, E. J.: Timing of millennial-scale climate change at Siple Dome, West Antarctica, during the last glacial period, Quaternary Sci. Rev., 24(12-13), 1333-1343, 2005.

Capron, E., Landais, A., Lemieux-Dudon, B., Schilt, A., Masson-Delmotte, V., Buiron, D., Chappellaz, J., DahlJensen, D., Johnsen, S., and Leuenberger, M.: Synchronizing EDML and NorthGRIP ice cores using $\delta^{18} \mathrm{O}$ of atmospheric oxygen $\left(\delta^{18} \mathrm{O}_{\mathrm{atm}}\right)$ and $\mathrm{CH}_{4}$ measurements over MIS5 (80-123 kyr), Quaternary Sci. Rev., 29(1-2), 222-234, doi:10.1016/j.quascirev.2009.07.014, 2010.

Castelnau O. and Duval P.: Simulations of anisotropy and fabric development in polar ices, Ann. Glaciol., 20, 277-282, 1994.

Castelnau, O., Shoji, H., Mangeney, A., Milsch, H., Duval, P., Miyamoto, A., Kawada, K., and Watanabe, O.: Anisotropic behavior of GRIP ices and flow in Central Greenland, Earth Planet. Sc. Lett., 154(1-4), 307-322, doi:10.1016/S0012821X(97)00193-3, 1998.

Chappellaz, J., Brook, E., Blunier, T., and Malaizé, B.: $\mathrm{CH}_{4}$ and $\delta^{18} \mathrm{O}$ of $\mathrm{O}_{2}$ records from Antarctic and Greenland ice: A clue for stratigraphic disturbance in the bottom part of the Greenland Ice Core, J. Geophys. Res., 102(C12), 26547-26557, doi:199710.1029/97JC00164, 1997.

Dällenbach, A., Blunier, T., Flückiger, J., Stauffer, B., Chappellaz, J., and Raynaud, D.: Changes in the atmospheric $\mathrm{CH}_{4}$ gradient between Greenland and Antarctica during the Last Glacial and the transition to the Holocene, Geophys. Res. Lett., 27(7), 10051008, doi:200010.1029/1999GL010873, 2000.

Delmas, R. J.: Free tropospheric reservoir of natural sulfate, J. Atmos. Chem., 14(1), 261-271, doi:10.1007/BF00115238, 1992.

Denman, K., Brasseur, G., Chidthaisong, A., Chidthaisong P., Ciais, P. M., Cox, R. E., Dickinson, D., Hauglustaine, C., Heinze, E., Holland, D., Jacob, U., Lohmann, S., Ramachandran, P. L., da Silva, Dias, Wofsy, S. C., and Zhang, X.: Couplings Between Changes in the Climate System and Biogeochemistry, in: Climate Change 2007: The Physical Science Basis. Contribution of Working Group I to the Fourth Assessment Report of the Intergovernmental Panel on Climate Change, edited by: Solomon, S., Qin, D., Manning, M., Chen, Z., Marquis, M., Averyt, K. B., Tignor, M., and Miller, H. L., Cambridge University Press, Cambridge, United Kingdom and New York, NY, USA, 2007.

Durand, G., Gagliardini, O., Thorsteinsson, T., Svensson, A., Kipfstuhl, S., and Dahl-Jensen, D.: Ice microstructure and fabric: an up-to-date approach for measuring textures, J. Glaciol., 52, 619630, doi:10.3189/172756506781828377, 2006.
Durand, G., Gillet-Chaulet, F., Svensson, A., Gagliardini, O., Kipfstuhl, S., Meyssonnier, J., Parrenin, F., Duval, P., and DahlJensen, D.: Change in ice rheology during climate variations -implications for ice flow modelling and dating of the EPICA Dome C core, Clim. Past, 3, 155-167, doi:10.5194/cp-3-1552007, 2007.

EPICA Community Members: Eight glacial cycles from an Antarctic ice core, Nature, 429(6992), 623-628, doi:10.1038/nature02599, 2004.

EPICA Community Members: One-to-one coupling of glacial climate variability in Greenland and Antarctica, Nature, 444(7116), 195-198, doi:10.1038/nature05301, 2006.

Epstein, S., Buchsbaum, R., Lowenstam, L., and Urey, H.: Carbonate-water isotopic temperature scale, Geol. Soc. Am. Bull, 62, 417-425, 1953.

Finkel, R. C. and Nishiizumi, K.: Beryllium 10 concentrations in the Greenland Ice Sheet Project 2 ice core from 3-40 ka, J. Geophys. Res., 102(C12), 26699-26706, doi:199710.1029/97JC01282, 1997.

Frezzotti, M., Bitelli, G., de Michelis, P., Deponti, A., Forieri, A., Gandolfi, S., Maggi, V., Mancini, F., Remy, F., and Tabacco, I. E.: Geophysical survey at Talos Dome, East Antarctica: the search for a new deep-drilling site, Ann. Glaciol., 39(1), 423432, 2004.

Frezzotti, M., Urbini, S., Proposito, M., Scarchilli, C., and Gandolfi, S.: Spatial and temporal variability of surface mass balance near Talos Dome, East Antarctica, J. Geophys. Res., 112(F2), 1-15, 2007.

Gagliardini, O. and Meyssonnier, J.: Simulation of anisotropic ice flow and fabric evolution along the GRIP-GISP2 flow line, central Greenland, Ann. Glaciol., 30, 217-223, 2000.

Goujon, C., Barnola, J. M., and Ritz, C.: Modeling the densification of polar firn including heat diffusion: Application to closeoff characteristics and gas isotopic fractionation for Antarctica and Greenland sites, J. Geophys. Res., 108, 101-1018, doi:200310.1029/2002JD003319, 2003.

Huber, C., Leuenberger, M., Spahni, R., Flückiger, J., Schwander, J., Stocker, T., Johnsen, S., Landais, A., and Jouzel, J.: Isotope calibrated Greenland temperature record over Marine Isotope Stage 3 and its relation to $\mathrm{CH}_{4}$, Earth Planet. Sc. Lett., 243(3-4), 504-519, doi:10.1016/j.epsl.2006.01.002, 2006.

Johnsen, S. J., Clausen, H. B., Dansgaard, W., Fuhrer, K., Gundestrup, N., Hammer, C. U., Iversen, P., Jouzel, J., Stauffer, B., and Steffensen, J. P.: Irregular glacial interstadials recorded in a new Greenland ice core, Nature, 359(6393), 311-313, doi:10.1038/359311a0, 1992.

Kawamura, K., Parrenin, F., Lisiecki, L., Uemura, R., Vimeux, F., Severinghaus, J. P., Hutterli, M. A., Nakazawa, T., Aoki, S., Jouzel, J., Raymo, M. E., Matsumoto, K., Hisakazu, N., Motoyama, H., Fujita, S., Goto-Azuma, K., Fujii, Y., and Watanabe, O.: Northern Hemisphere forcing of climatic cycles in Antarctica over the past 360000 years, Nature, 448(7156), 912-916, doi:10.1038/nature06015, 2007.

Landais, A., Chappellaz, J., Delmotte, M., Jouzel, J., Blunier, T., Bourg, C., Caillon, N., Cherrier, S., Malaizé, B., and MassonDelmotte, V.: A tentative reconstruction of the last interglacial and glacial inception in Greenland based on new gas measurements in the Greenland Ice Core Project (GRIP) ice core, J. Geophys. Res, 108, 4563-4572, 2003. 
Landais, A., Barnola, J. M., Kawamura, K., Caillon, N., Delmotte, M., van Ommen, T., Dreyfus, G., Jouzel, J., Masson-Delmotte, V., and Minster, B.: Firn-air $\delta^{15} \mathrm{~N}$ in modern polar sites and glacial - interglacial ice: a model-data mismatch during glacial periods in Antarctica?, Quaternary Sci. Rev., 25(1-2), 49-62, 2006.

Lemieux-Dudon, B., Parrenin, F., and Blayo, E.: A probabilistic method to construct a common and optimal chronology for an ice core, in Physics of Ice Core Records, Hondoh, Hokkaido University Collection of Scholarly and Academic Papers (Ed.), 2009.

Lemieux-Dudon, B., Blayo, E., Petit, J. R., Waelbroeck, C., Svensson, A., Ritz, C., Barnola, J. M., Narcisi, B. M., and Parrenin, F.: Consistent dating for Antarctic and Greenland ice cores, Quaternary Sci. Rev., 29(1-2), 8-20, doi:10.1016/j.quascirev.2009.11.010, 2010.

Lisiecki, L. E. and Raymo, M.: A Pliocene-Pleistocene stack of 57 globally distributed benthic $\delta^{18} \mathrm{O}$ records, Paleoceanography, 20(2), doi:10.1029/2005PA001164, 2005.

Lliboutry, L. and Ritz, C.: Steady flow of nonlinear viscous-fluid (glen body) around a perfectly smooth sphere, Ann. Geophys., 34(2), 133-146, 1978.

Loulergue, L., Parrenin, F., Blunier, T., Barnola, J.-M., Spahni, R., Schilt, A., Raisbeck, G., and Chappellaz, J.: New constraints on the gas age-ice age difference along the EPICA ice cores, 0-50 kyr, Clim. Past, 3, 527-540, doi:10.5194/cp-3-527-2007, 2007.

Loulergue, L., Schilt, A., Spahni, R., Masson-Delmotte, V., Blunier, T., Lemieux, B., Barnola, J. M., Raynaud, D., Stocker, T. F., and Chappellaz, J.: Orbital and millennial-scale features of atmospheric $\mathrm{CH}_{4}$ over the past 800000 years, Nature, 453(7193), 383-386, doi:10.1038/nature06950, 2008.

Mackintosh, A., White, D., Fink, D., Gore, D. B., Pickard, J., and Fanning, P. C.: Exposure ages from mountain dipsticks in Mac. Robertson Land, East Antarctica, indicate little change in icesheet thickness since the Last Glacial Maximum, Geology, 35(6), 551-554, doi:10.1130/G23503A, 2007.

Magand, O., Frezzotti, M., Pourchet, M., Stenni, B., Genoni, L., and Fily, M.: Climate variability along latitudinal and longitudinal transects in East Antarctica, Ann. Glaciol., 39(1), 351-358, 2004.

Mangeney, A., Califano, F., and Hutter, K.: A numerical study of anisotropic, low Reynolds number, free surface flow for ice sheet modeling, J. Geophys. Res., 102(B10), 22749-22764, doi:199710.1029/97JB01697, 1997.

Masson-Delmotte, V., Dreyfus, G., Braconnot, P., Johnsen, S., Jouzel, J., Kageyama, M., Landais, A., Loutre, M.-F., Nouet, J., Parrenin, F., Raynaud, D., Stenni, B., and Tuenter, E.: Past temperature reconstructions from deep ice cores: relevance for future climate change, Clim. Past, 2, 145-165, doi:10.5194/cp2-145-2006, 2006.

Meneghel, M., Bondesan, A., Salvatore, M., and Orombelli, G.: A model of the glacial retreat of upper Rennick Glacier, Victoria Land, Antarctica, Ann. Glaciol., 29, 225-230, 1999.

Merlivat, L.: Molecular diffusivities of $\mathrm{H}_{2}^{16} \mathrm{O}, \mathrm{HD}^{16} \mathrm{O}$ and $\mathrm{H}_{2}^{18} \mathrm{O}$ in gases, J. Chem. Phys., 69(6), 2864, doi:10.1063/1.436884, 1978.

Montagnat M., Broquet, A., Schlitz, P., Buiron, D., Arnaud, L., and Kipfstuhl, S.: Measurement and numerical simulation of fabric evolution along Talos Dome ice core, Antarctica, in preparation, n.d., 2011.

Morgan, V., Delmotte, M., van Ommen, T, Jouzel, J., Chappellaz,
J., Woon, S., Masson-Delmotte, V., and Raynaud, D.: Relative Timing of Deglacial Climate Events in Antarctica and Greenland, Science, 297(5588), 1862-1864, doi:10.1126/science.1074257, 2002.

Morse, D. L., Waddington, E. D., and Steig, E. J.: Ice Age storm trajectories inferred from radar stratigraphy at Taylor Dome, Antarctica, Geophys. Res. Lett., 25(17), 3383-3386, 1998.

Morse, D. L., Waddington, E. D., and Rasmussen, L. A.: Ice deformation in the vicinity of the ice-core site at Taylor Dome, Antarctica, and a derived accumulation rate history, J. Glaciol., 53(182), 449-460, 2007.

Parrenin, F., Remy, F., Ritz, C., Siegert, M. J., and Jouzel, J.: New modeling of the Vostok ice flow line and implication for the glaciological chronology of the Vostok ice core, J. Geophys. Res, 109, 1-14, 2004.

Parrenin, F., Barnola, J.-M., Beer, J., Blunier, T., Castellano, E., Chappellaz, J., Dreyfus, G., Fischer, H., Fujita, S., Jouzel, J., Kawamura, K., Lemieux-Dudon, B., Loulergue, L., MassonDelmotte, V., Narcisi, B., Petit, J.-R., Raisbeck, G., Raynaud, D., Ruth, U., Schwander, J., Severi, M., Spahni, R., Steffensen, J. P., Svensson, A., Udisti, R., Waelbroeck, C., and Wolff, E.: The EDC3 chronology for the EPICA Dome C ice core, Clim. Past, 3, 485-497, doi:10.5194/cp-3-485-2007, 2007 a.

Parrenin, F., Dreyfus, G., Durand, G., Fujita, S., Gagliardini, O., Gillet, F., Jouzel, J., Kawamura, K., Lhomme, N., MassonDelmotte, V., Ritz, C., Schwander, J., Shoji, H., Uemura, R., Watanabe, O., and Yoshida, N.: 1-D-ice flow modelling at EPICA Dome C and Dome Fuji, East Antarctica, Clim. Past, 3, 243-259, doi:10.5194/cp-3-243-2007, 2007b.

Petit, J. R., Jouzel, J., Raynaud, D., Barkov, N. I., Barnola, J. M., Basile, I., Bender, M., Chappellaz, J., Davis, M., Delaygue, G., Delmotte, M. , Kotlyakov, V. M., Legrand, M., Lipenkov, V. Y., Lorius, C., Pépin, L., Ritz, C., Saltzman, E., and Stievenard, M.: Climate and atmospheric history of the past 420000 years from the Vostok ice core, Antarctica, Nature, 399(6735), 429436, doi:10.1038/20859, 1999.

Pettit, E., Thorsteinsson, T., Jacobson, H., and Waddington, E. D.: The role of crystal fabric in flow near an ice divide, J. Glaciol., 53(181), 277-288, 2007.

Raisbeck, G. M. and Yiou, F.: ${ }^{10}$ Be in polar ice and atmospheres, Ann. Glaciol., 7, 138-140, 1985.

Raisbeck, G., Yiou, F., Jouzel, J., Petit, J. R., Barkov, N., and Bard, E.: ${ }^{10} \mathrm{Be}$ deposition at Vostok, Antarctica, during the last 50000 years and its relationship to possible cosmogenic production variations during this period, Bard E \& Broecker WS eds: The Last Deglaciation: Absolute and Radiocarbon Chronologies, NATO ASI series, I, 2, 127-140, 1992.

Rasmussen, S. O., Andersen, K. K., Svensson, A. M., Steffensen, J. P., Vinther, B. M., Clausen, H. B., Siggaard-Andersen, M., Johnsen, S. J., Larsen, L. B., Dahl-Jensen, D., Bigler, M., Rothlisberger, R., Fischer, H., Goto-Azuma, K., Hansson, M. E., and Ruth, U.: A new Greenland ice core chronology for the last glacial termination, J. Geophys. Res., 111(D6), 1-16, doi:10.1029/2005JD006079, 2006.

Ritz, C., Rommelaere, V., and Dumas, C.: Modeling the evolution of Antarctic ice sheet over the last 420000 years: Implications for altitude changes in the Vostok region, J. Geophys. Res., 106(D23), 31943-31964, doi:200110.1029/2001JD900232, 2001. 
Russell-Head, D. and Wilson, C.: Automated fabric analyzer system for quartz and ice, Geol. Soc. Aust., Abstract 64, 159 pp., 2001.

Ruth, U., Barnola, J.-M., Beer, J., Bigler, M., Blunier, T., Castellano, E., Fischer, H., Fundel, F., Huybrechts, P., Kaufmann, P., Kipfstuhl, S., Lambrecht, A., Morganti, A., Oerter, H., Parrenin, F., Rybak, O., Severi, M., Udisti, R., Wilhelms, F., and Wolff, E.: "EDML1": a chronology for the EPICA deep ice core from Dronning Maud Land, Antarctica, over the last 150000 years, Clim. Past, 3, 475-484, doi:10.5194/cp-3-475-2007, 2007.

Scarchilli, C., Frezzotti, M., and Ruti, P. M.: Snow precipitation at four ice core sites in East Antarctica: provenance, seasonality and blocking factors, Clim. Dynam., in press, doi:10.1007/s00382-010-0946-4, 2010.

Schüpbach, S., Federer, U., Kaufmann, P. R., Hutterli, M. A., Buiron, D., Blunier, T., Fischer, H., and Stocker, T. F.: A New Method for High-Resolution Methane Measurements on Polar Ice Cores Using Continuous Flow Analysis, Environ. Sci. Technol., 43(14), 5371-5376, doi:10.1021/es9003137, 2009.

Schwander, J., Sowers, T., Barnola, J. M., Blunier, T., Fuchs, A., and Malaizé, B.: Age scale of the air in the summit ice: implication for glacial-interglacial temperature change, J. Geophys. Res., 102(D16), 19483-19493, doi:199710.1029/97JD01309, 1997.

Sowers, T., Bender, M., Raynaud, D., Korotkevich, Y. S., and Orchardo, J.: The $\delta^{18} \mathrm{O}$ of atmospheric $\mathrm{O}_{2}$ from air inclusions in the Vostok Ice Core: Timing of $\mathrm{CO}_{2}$ and ice volume changes during the penultimate deglaciation, Paleoceanography, 6(6), 679, doi:10.1029/91PA02023, 1991.

Sowers, T. and Bender, M.: Climate Records Covering the Last Deglaciation, Science, 269(5221), 210-214, doi:10.1126/science.269.5221.210, 1995.

Spahni, R., Schwander, J., Flückiger, J., Stauffer, B., Chappellaz, J., and Raynaud, D.: The attenuation of fast atmospheric $\mathrm{CH}_{4}$ variations recorded in polar ice cores, Geophys. Res. Lett, 30(11), 1571, 25-1-25-4, 2003.

Spahni, R., Chappellaz, J., Stocker, T., Loulergue, L., Hausmmann, G., Kawamura, K., Flückiger, J., Schwander, J., Raynaud, D., Masson-Delmotte, V., and Jouzel, J.: Atmospheric Methane and Nitrous Oxide of the Late Pleistocene from Antarctic Ice Cores, Science, 310(5752), 1317-1321, doi:10.1126/science.1120132, 2005.

Steig, E. J., Brook, E., White, J., and Sucher, C.: Synchronous Climate Changes in Antarctica and the North Atlantic, Science, 282(5386), 92-95, doi:10.1126/science.282.5386.92, 1998.

Stenni, B., Masson-Delmotte, V., Johnsen, S., Jouzel, J., Longinelli, A., Monnin, E., Röthlisberger, R., and Selmo, E.: An oceanic cold reversal during the last deglaciation, Science, 293(5537), 2074-2077, 2001.
Stenni, B., Proposito, M., Gragnani, R., Flora, O., Jouzel, J., Falourd, S., and Frezzotti, M.: Eight centuries of volcanic signal and climate change at Talos Dome (East Antarctica), J. Geophys. Res., 107(D9), 4076, doi:10.1029/2000JD000317, 2002.

Stenni, B., Buiron, D., Frezzotti, M., Albani, S., Barbante, C., Bard, E., Barnola, J. M., Baroni, M., Baumgartner, M., Bonazza, M., Capron, E., Castellano, E., Chappellaz, J., Delmonte, B., Falourd, S., Genoni, L., Iacumin, P., Jouzel, J., Kipfstuhl, S., Landais, A., Lemieux-Dudon, B., Maggi, V., Masson-Delmotte, V., Mazzola, C., and Minster, B.: Expression of the bipolar seesaw in Antarctic climate records during the last deglaciation, Nat. Geosci., 4, 46-49, doi:10.1038/ngeo1026, 2011.

Svensson, A., Andersen, K. K., Bigler, M., Clausen, H. B., Dahl-Jensen, D., Davies, S. M., Johnsen, S. J., Muscheler, R., Rasmussen, S. O., and Röthlisberger, R.: The Greenland Ice Core Chronology 2005, 15-42 ka. Part 2: comparison to other records, Quaternary Sci. Rev., 25(23-24), 3258-3267, doi:10.1016/j.quascirev.2006.08.003, 2006.

Svensson, A., Andersen, K. K., Bigler, M., Clausen, H. B., DahlJensen, D., Davies, S. M., Johnsen, S. J., Muscheler, R., Parrenin, F., Rasmussen, S. O., Rthlisberger, R., Seierstad, I., Steffensen, J. P., and Vinther, B. M.: A 60000 year Greenland stratigraphic ice core chronology, Clim. Past, 4, 47-57, doi:10.5194/cp-4-472008, 2008.

Urbini, S., Frezzotti, M., Gandolfi, S., Vincent, C., Scarchilli, C., Vittuari, L., and Fily, M.: Historical behaviour of Dome C and Talos Dome (East Antarctica) as investigated by snow accumulation and ice velocity measurements, Global. Planet. Change, 60(3-4), 576-588, 2008.

Van der Veen, C. and Whillans, I.: Development of fabric in ice, Cold Reg. Sci. Technol., 22(2), 171-195, doi:10.1016/0165232X(94)90027-2, 1994.

Vinther, B. M., Clausen, H. B., Johnsen, S. J., Rasmussen, S. O., Andersen, K. K., Buchardt, S. L., Dahl-Jensen, D., Seierstad, I. K., Siggaard-Andersen, M., Steffensen, J. P., Svensson, A., Olsen, J., and Heinemeier, J.: A synchronized dating of three Greenland ice cores throughout the Holocene, J. Geophys. Res., 111(D13), doi:10.1029/2005JD006921, 2006.

Watanabe, O., Jouzel, J., Johnsen, S., Parrenin, F., Shoji, H., and Yoshida, N.: Homogeneous climate variability across East Antarctica over the past three glacial cycles, Nature, 422(6931), 509-512, doi:10.1038/nature01525, 2003.

Woodcock, N.: Specification of fabric shapes using an eigenvalue method, Geol. Soc. Of America Bulletin, 88(1231-1236), 1977. 